\title{
I linguaggi della rappresentazione: i disegni della fontana di Orione a Messina tra il XVI e il XXI secolo
}

\author{
Alessio Altadonna \\ Adriana Arena
}

\section{Abstract}

Partendo dalla ormai ben consolidata considerazione che il Disegno è strumento insostituibile di comunicazione e che, in relazione alla diversa formazione degli autori e al proprio contesto storico o ai differenti destinatari o fruitori delle loro opere, l'esito grafico assume caratteristiche tali da essere adeguatamente percepito, il paper propone un excursus sugli apparati iconografici relativi alla fontana di Orione, realizzata a Messina nel XVI secolo. Dall'analisi dei disegni è possibile tracciare interessanti percorsi di conoscenza e di approfondimento sulla storia dei modi di rappresentare l'architettura dal periodo in cui l'oggetto viene ideato fino ai giorni nostri, constatando altresì i diversi gradi di approssimazione che contraddistinguono gli elaborati rispetto all'oggetto reale.

Parole chiave

linguaggio grafico, rappresentazione, rilievo, fontana di Orione, Messina.

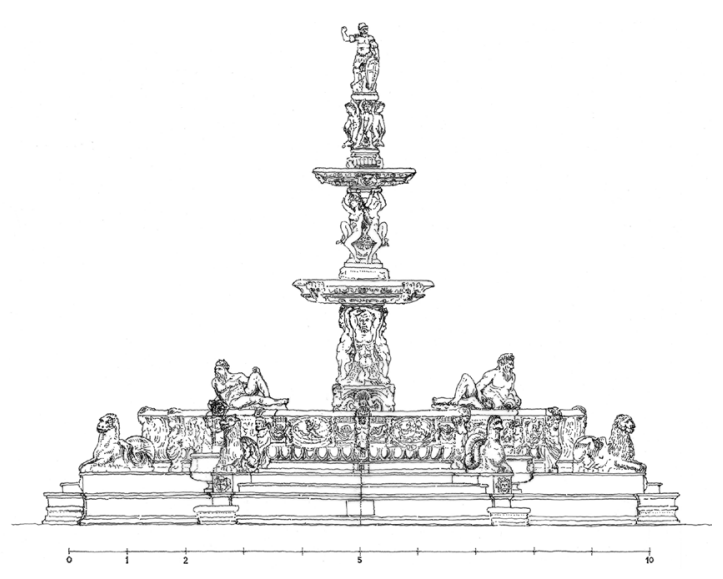


"Niente posso costruire, né comunicare - nessuno strumento, nessuna macchina, nessuna città, nessuna società - se non tramite immagini mentali, o idee. Le infinite forme di disegno e le infinite formazioni dei segni e dei simboli sono traduzioni sintetiche sensibili delle immagini mentali: hanno anzitutto valenza conoscitiva e comunicativa, in quanto dicono in modi diversi l'essenza, la struttura e il significato delle singole realtà" [Pier Paolo Ottonello 200I].

\section{Introduzione}

Partendo dalla ormai ben consolidata considerazione che il Disegno è strumento insostituibile di comunicazione e che, in relazione alla diversa formazione degli autori e al proprio contesto storico o ai differenti destinatari o fruitori delle loro opere, l'esito grafico assume caratteristiche tali da essere adeguatamente percepito, è possibile tracciare interessanti percorsi di conoscenza e di approfondimento sulla storia dei modi di rappresentare l'architettura. Percorsi che assumono connotati specifici se l'oggetto di studio è sempre lo stesso analizzato attraverso il linguaggio delle sue diverse rappresentazioni realizzate nel corso dei secoli. Questo genere di indagine presuppone la conoscenza approfondita dei modi in cui, nei secoli, si è sviluppata l'interpretazione del disegno di architettura, tema che, ovviamente, in questa sede, può soltanto essere accennato per alcuni punti e che sarà spunto di ulteriori sviluppi di ricerca in futuro. L'oggetto in questione è la monumentale fontana di Orione (XVI sec.) che si erge nella piazza della cattedrale di Messina. (Ad. A.).

\section{Brevi cenni storici e descrittivi}

Nel 1547 Giovanni Angiolo Montorsoli, frate servita di origini fiorentine e allievo di Michelangelo Buonarroti, giunge a Messina con l'incarico di progettare una fontana monumentale "con un ornamento grandissimo di statue" [Aricò 20 13, p. I] nella piazza antistante la cattedrale in sostituzione di una piccola fonte considerata la conclusione di un'importante operazione di ingegneria idraulica condotta per imbrigliare le acque del torrente Camaro a servizio della città. La realizzazione della fontana diventa l'occasione "per avviare un progetto rinascimentale e riscrivere una palingenesi del luogo più rappresentativo della città" [Aricò 2013, p. 13].

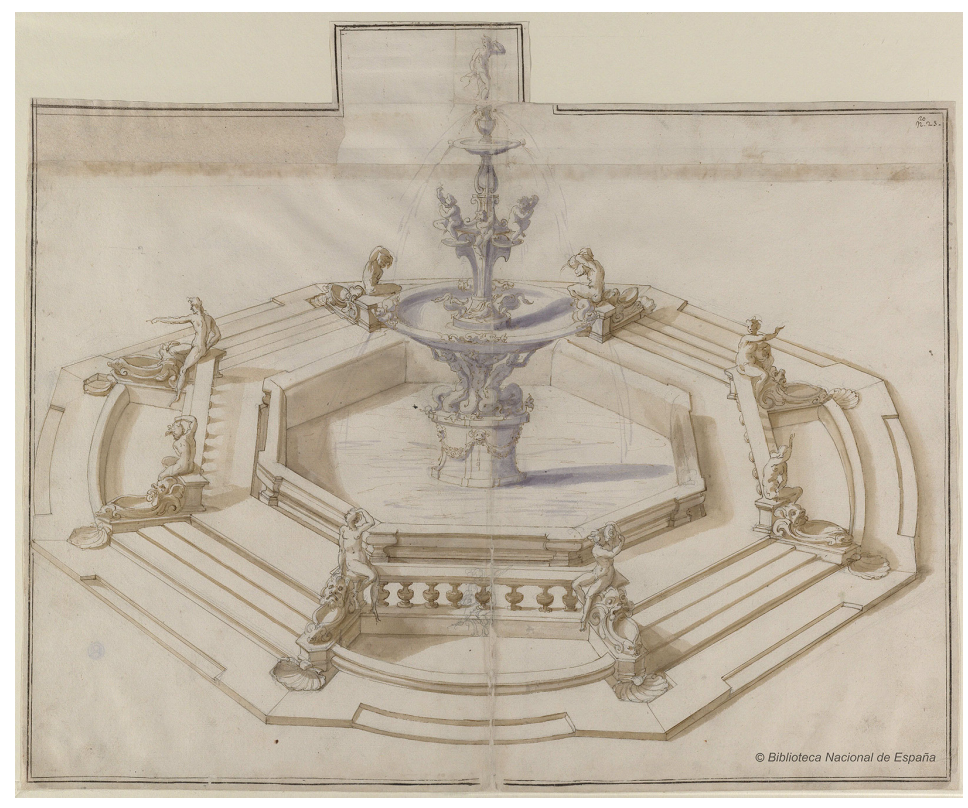


I lavori si concludono nel I550 e il monumento viene inaugurato tre anni dopo. Considerata una delle più belle fontane d'Italia, sarà oggetto di interesse da parte di artisti locali e viaggiatori stranieri che, a titolo diverso, e con metodi di rappresentazione differenti, la riprodurranno, o ne descriveranno le forme in testi letterari [Vasari I568] [2], producendo un interessante corpus iconografico da cui trarre spunti di riflessione in materia di disegno e delle sue varie forme di rappresentazione. Secondo gli studi condotti da Mario Manganaro, sotto il profilo geometrico, la fontana poggia su un basamento dodecagonale irregolare: "Il fatto che non sia un poligono regolare non è casuale, perché la vera figura geometrica della vasca, essendo un poligono concavo ... è formata da venti lati. Considerando, infatti, altri otto lati, ognuno dei quali non raggiunge il metro, dal punto di vista geometrico bisogna aggiungerli agli altri per avere il totale del perimetro" [Manganaro 2017, p. I7I]. Più che di un oggetto scultoreo gli storici parlano di un'architettura "nascosta" dalla scultura, talmente imponente è l'apparato decorativo da sottrarre l'attenzione dell'osservatore al suo assetto compositivo: un sistema geometrico basato sul numero 4 per cui la vasca principale sorge su un basamento costituito da tre gradini il cui andamento geometrico è interrotto da quattro rientranze con vasche, decorate lateralmente da mascheroni e fiancheggiate da mostri marini, su cui incombono altrettante divinità fluviali: il Nilo, il Tevere, l'Ebro e il Camaro (sorgente d'acqua locale). L'acqua scorre attraverso anfore possedute da queste statue per confluire nelle vasche sottostanti quindi in altre di dimensioni minori collocate ai piedi della gradinata. L'alzato della grande vasca è decorato da bassorilievi a tema mitologico. Dal centro s'innalza un gruppo di figure mostruose che sorregge la seconda vasca dalla quale, a sua volta si elevano quattro sculture femminili, le ninfe, che sostengono la vasca minore con al centro quattro putti sulle cui spalle grava la statua di Orione col fedele cane Sirio. (Ad. A.).

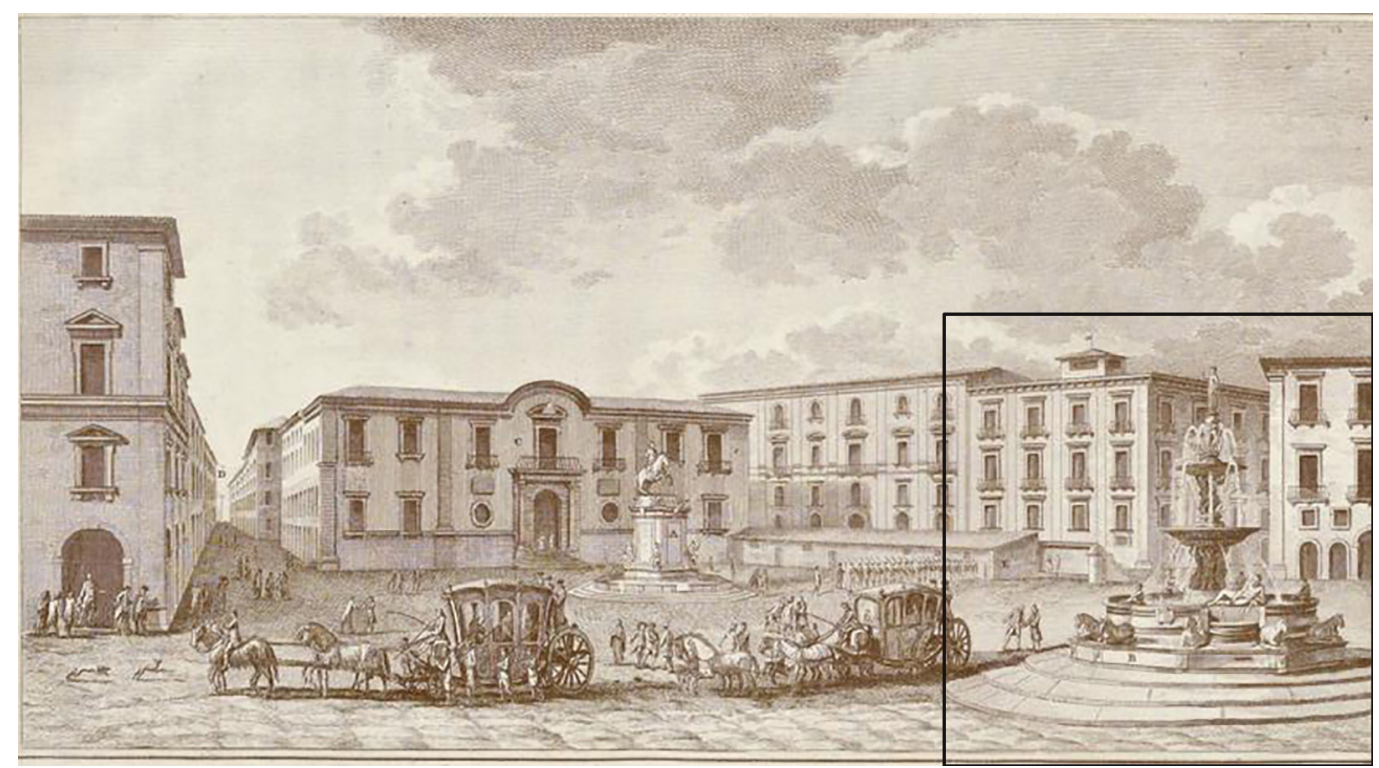

\section{L'album Casale}

Presso la Biblioteca Nazionale di Madrid, nella collezione Dibujos de arquitectura, è conservata una raccolta di disegni che prende il nome dal suo autore, il frate Giovanni Vincenzo Casale, scultore e architetto e allievo del Montorsoli. Allinterno dell'album, tra gli altri, compaiono alcuni disegni attribuiti all'autore della fontana di Orione e, proprio di quest'ultima, si ha una tra le prime rappresentazioni conosciute. Si tratta di uno studio prospettico, datato 1547, realizzato con la matita nera ripassata a inchiostro con acquerellature seppia e azzurro [Bustamante, Marías 199I]. La rappresentazione in prospettiva rientra nella pratica 
disegnativa degli architetti rinascimentali italiani, tipicamente provenienti da una formazione artistica, in contrapposizione con i maestri del nord Europa che, invece, anticipano l'utilizzo pressocché sistematico del metodo delle proiezioni ortogonali nel disegno delle architetture gotiche [Ackerman 2003]. Rispetto all'assetto attuale il basamento si presenta con un andamento mistilineo, assimilabile a un ottagono con il primo gradino che assume alternativamente una forma curva o rettilinea interrotto, in corrispondenza delle otto sculture delle divinità (in quella attuale sono quattro), da una cuspide. Quattro sono le vasche inferiori ai cui lati sono collocate le suddette statue poggiate ad angolo tra l'estremità di una balaustra e dei mascheroni dai quali l'acqua sarebbe confluita in vasche minori. Superato l'impianto basamentale la forma ottagonale è confermata nella definizione della vasca principale al centro della quale, su un piedistallo a sezione circolare, arricchito lateralmente da festoni decorativi, un gruppo scultoreo di figure sorregge la seconda vasca. Da questa, un ulteriore piedistallo dalla forma variamente articolata e impreziosito alla base da quattro figure di volatili e più su da altrettanti putti, sostiene la vasca sommitale su cui si erge Orione il fondatore della città. Analizzando con attenzione il disegno si notano gli schizzi d'acqua che dall'alto cadono sui livelli sottostanti conferendo allo stesso un carattere realistico (fig. I). Non avendo a disposizione altri disegni relativi al monumento attribuibili al suo progettista non è possibile formulare ipotesi relative ai ripensamenti che hanno portato alla soluzione definitiva. Resta di fatto, il disegno dell'album Casale, una preziosa testimonianza di un modo di rappresentare in un preciso periodo storico: le varianti successive e gli studi condotti dagli storici suggerirebbero un'evoluzione nel pensiero del suo artefice volta a esaltare la complessità sia geometrica che decorativa del monumento, aspetti appena accennati nel disegno contenuto nell'album. (Ad. A.).

\section{Le incisioni di Francesco Sicuro e di Pierre Gabriel Berthault}

Seppure in scala di minor dettaglio poiché inserite in vedute urbane è interessante il confronto tra le rappresentazioni del monumento eseguite da Francesco Sicuro (1746-1826) e pubblicata all'interno del Voyage pittoresque des isles de Sicile, de Malte et de Lipari (I735| 8| 3, vol. II) di Jean-Pierre Louis Laurent Houël e da Pierre Gabriel Berthault (I737- | 83 I) e

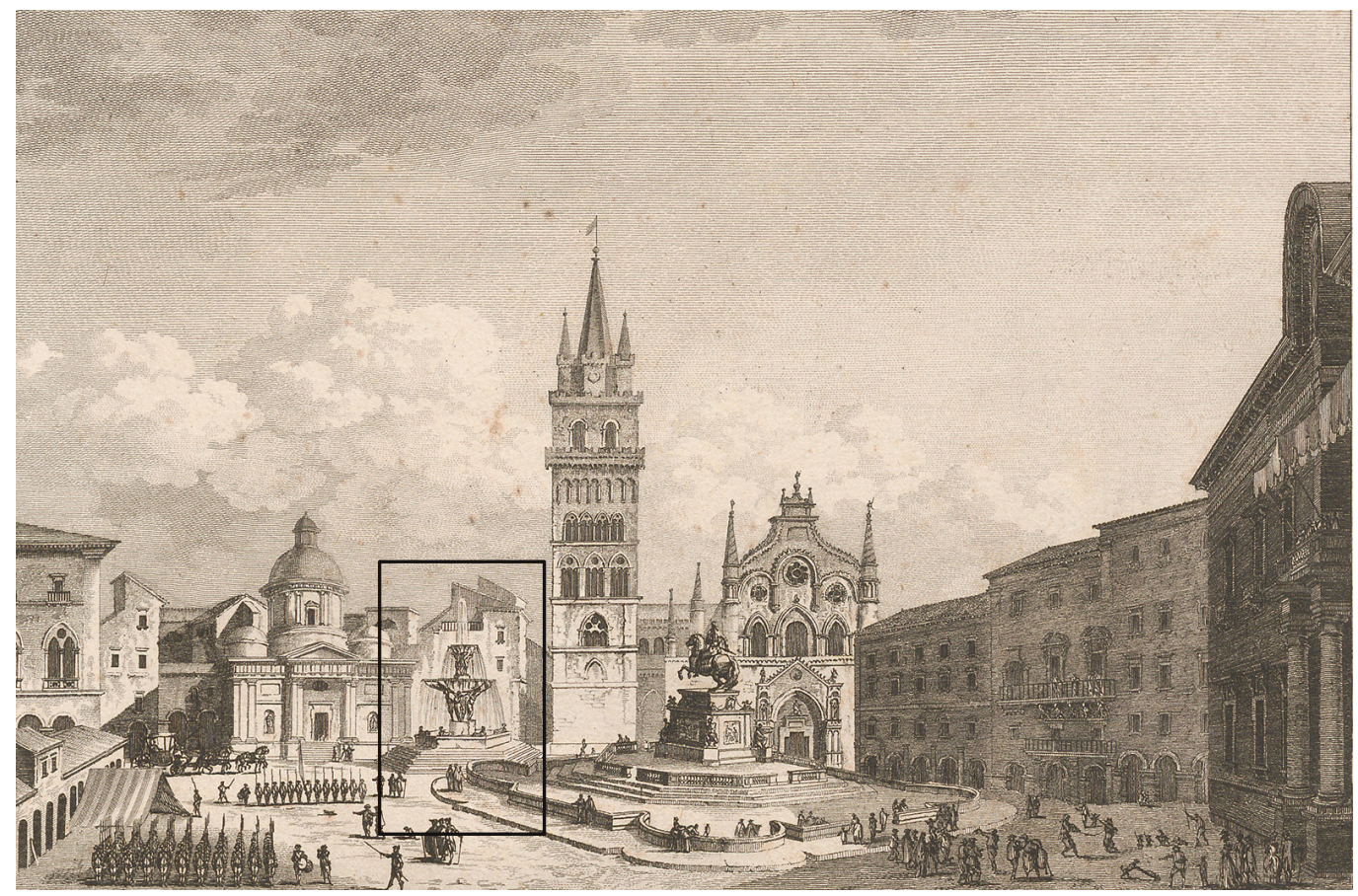


inserita nel Voyage pittoresque ou description des royaumes de Naples et de Sicile ( I78 I- I 786 vol. IV) di Richard de Saint-Non.

Nel descrivere l'opera Houël ne parla come di "une très-belle fontaine de marbre ornée de beaucoup de figures d'hommes \& d'animaux" e Sicuro la rappresenta rivolgendo le spalle dell'osservatore verso la cattedrale lasciandone in ombra una parte. Pur nella sommarietà della descrizione si distinguono nettamente gli elementi scultorei principali dell'opera e la presenza di figure umane accanto dà un'idea generale della percezione della monumentalità delle sue proporzioni (fig. 2).

Saint-Non ne parla come di "une jolie fontaine d'eaux jaillissantes" che insieme al monumento equestre del re spagnolo Carlo Il concorrono a definire l'aspetto ornamentale della piazza. Nellincisione di Berthault, il basamento della fontana sembrerebbe assumere una forma esagonale dando slancio, con un suo maggiore sviluppo in verticale rispetto a quello reale, alla parte basamentale dell'opera (fig. 3).

Le ridotte dimensioni, in entrambi i casi, determinano "una sorta di inversione del processo della conoscenza: per conoscere l'oggetto reale nella sua totalità, noi tendiamo sempre ad assumere come punto di partenza le sue diverse parti ... La riduzione di scala inverte questa situazione: più piccola la totalità dell'oggetto appare meno temibile, per il fatto di essere quantitativamente diminuita, essa ci sembra qualitativamente semplificata" [Lévi-Strauss 1964, pp. 34 e sgg.]. (Ad. A.).

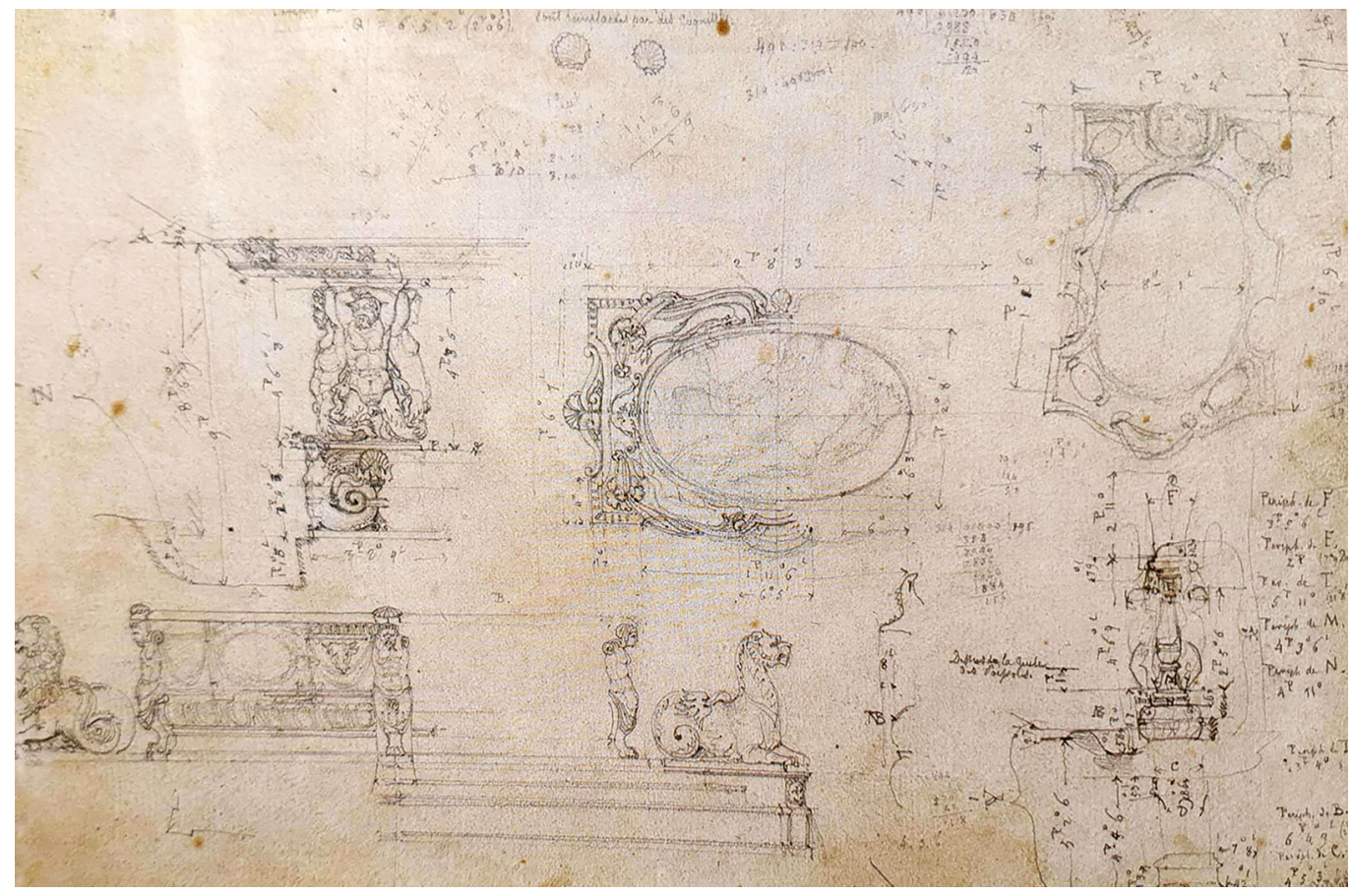

\section{I rilievi di Jacob Ignaz Hittorff}

Nel I 823 l'architetto tedesco Jacob Ignaz Hittorff, insieme a Ludwig Wilhelm von Zanth e a Wilhelm Stier, durante un soggiorno in Sicilia esegue una serie di rilievi della fontana di Orione considerati ancora oggi tra i più raffinati esistenti e custoditi presso la Biblioteca di Colonia. Alle planches inserite nell'Architecture moderne de la Sicile (1835), si aggiungono i disegni preparatori e i rilievi metrici originali dai quali, grazie alle recenti pubblicazioni [Kiene 20 I3], è stato possibile formulare nuove riflessioni sulle metodologie operative messe in atto da Hittorff che travalicano "la logica e la pratica tipica della letteratura delle esperienze di viaggio" [Lo Curzio 20 17, p. 49]. La meticolosità nell'approccio al rilievo e la conseguente 
Fig. 5. Jacob Ignaz Hittorff Plan et élévation partielle de la grande fontaine sur la place de la Cathédrale a Messine (da: J. I. Hittorff, L. Zanth, Architecture m.Zanth, Architecture 1835, tav. n. 26)

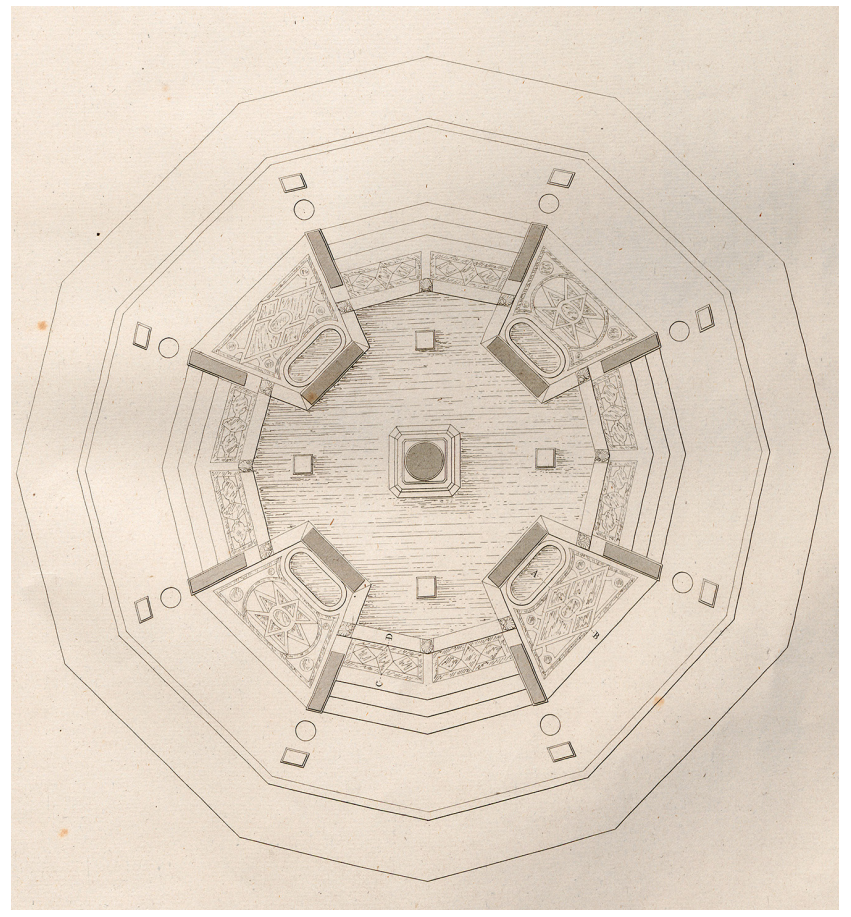

restituzione grafica testimoniano un'attenzione al monumento che va ben oltre i suoi aspetti artistici esaltandone il ruolo catalizzatore nello spazio urbano in cui esso è collocato. Non potendo isolare all'interno dei singoli disegni l'apporto di ciascuno dei tre rilevatori è però possibile, dal confronto tra i disegni pubblicati e gli originali, formulare delle considerazioni sia sul tratto che, in questi ultimi, appare sicuro e disinvolto nel delineare le figure e gli ornati benché si tratti di disegni preparatori, che sulle informazioni di carattere dimensionale, sicuramente esaustive e dettagliate, elementi tutti che denotano la forte impronta neoclassica e lo spirito illuministico che informano tutta l'operazione di rilievo [Manganaro 20 I7, p. I66] (fig. 4): interessante notare la scelta, per la proiezione orizzontale dell'intero complesso scultoreo, di più piani di sezione a quote diverse forse per evidenziare in un unico grafico i tratti salienti dell'opera (fig. 5). L'uso delle proiezioni ortogonali, introdotte e diffuse da Monge

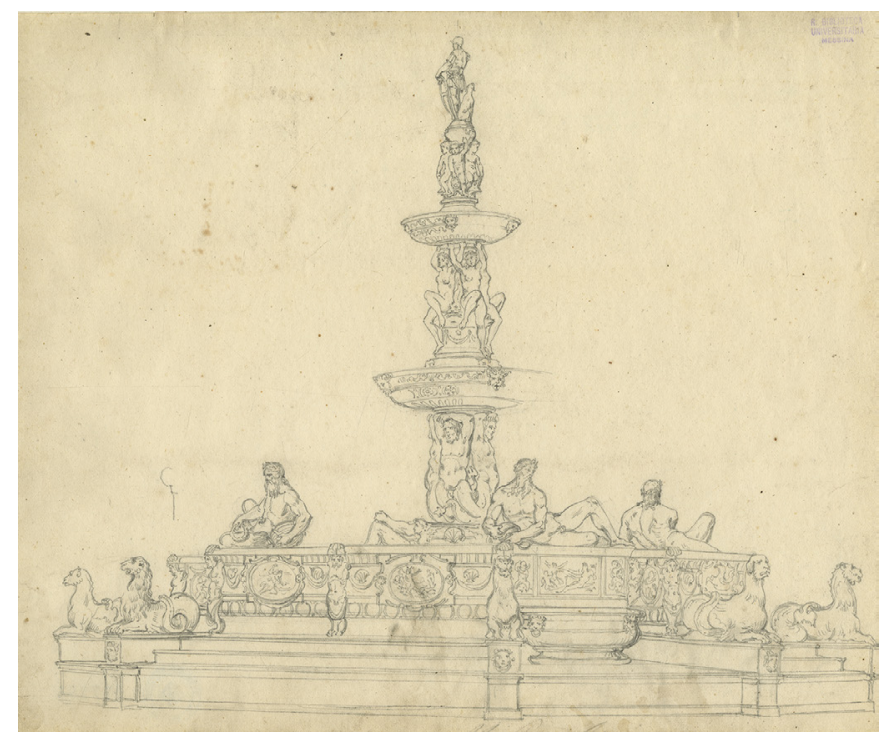

Fig. 6. Michele Panebianco, Veduta prospettica

della fontana di Orione, s.d. (Biblioteca Regionale di

Messina). 
Fig. 7. Luigi Di Giovanni, Schizzi preparatori per la fontana di Orione, s.d. (Museo Regionale di Messina)

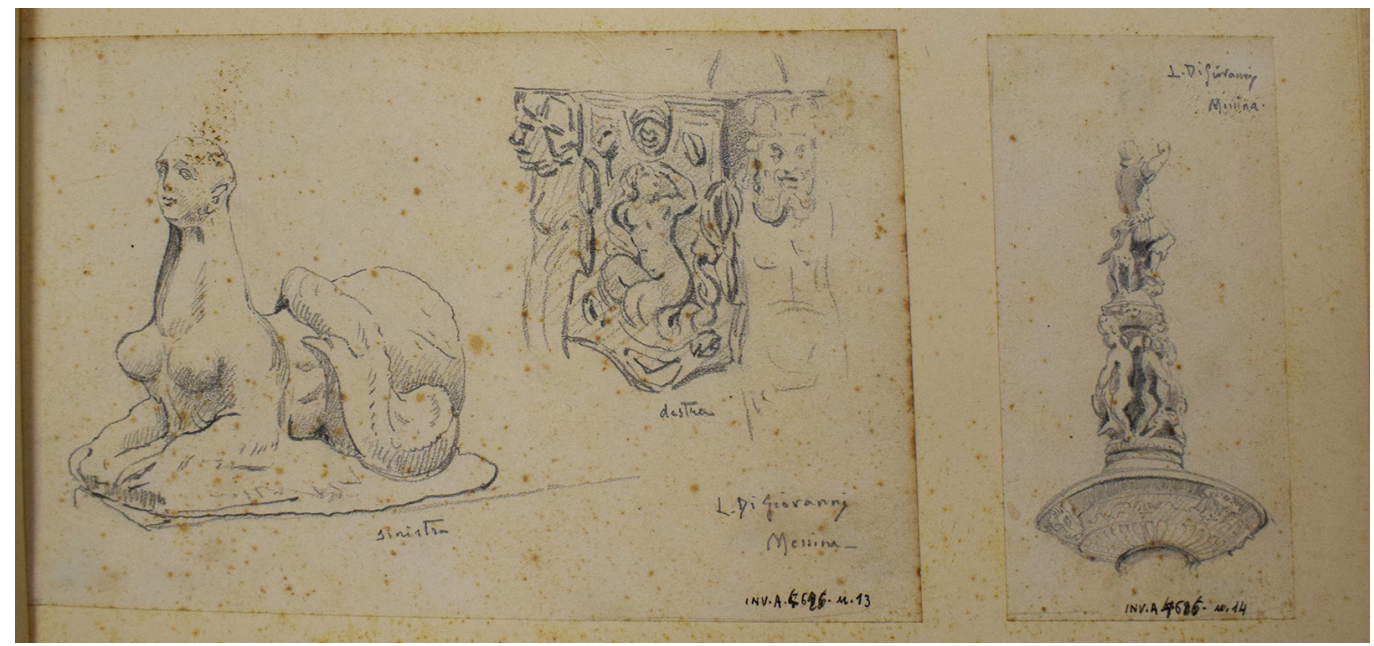

con la pubblicazione della sua opera Géométrie descriptive (1799), d'altronde, è il tratto che caratterizza e rende unico il lavoro di Hittorff rispetto a quello dei viaggiatori suoi predecessori e dagli altri disegnatori con maggiore inclinazione verso i modelli pittoreschi che lo seguiranno: "con le proiezioni geometriche di Monge, la quotatura e le vedute prospettiche, è possibile ricostruire scientificamente ed interamente gli edifici esaminati attraverso un'astrazione che esclude l'uso soggettivo del chiaroscuro o delle ombre che potrebbero determinare un effetto pittorico o prevaricare il senso nitido ed obbiettivo della costruzione architettonica" [Foderà 1982, p. 89]. (Ad.A.).

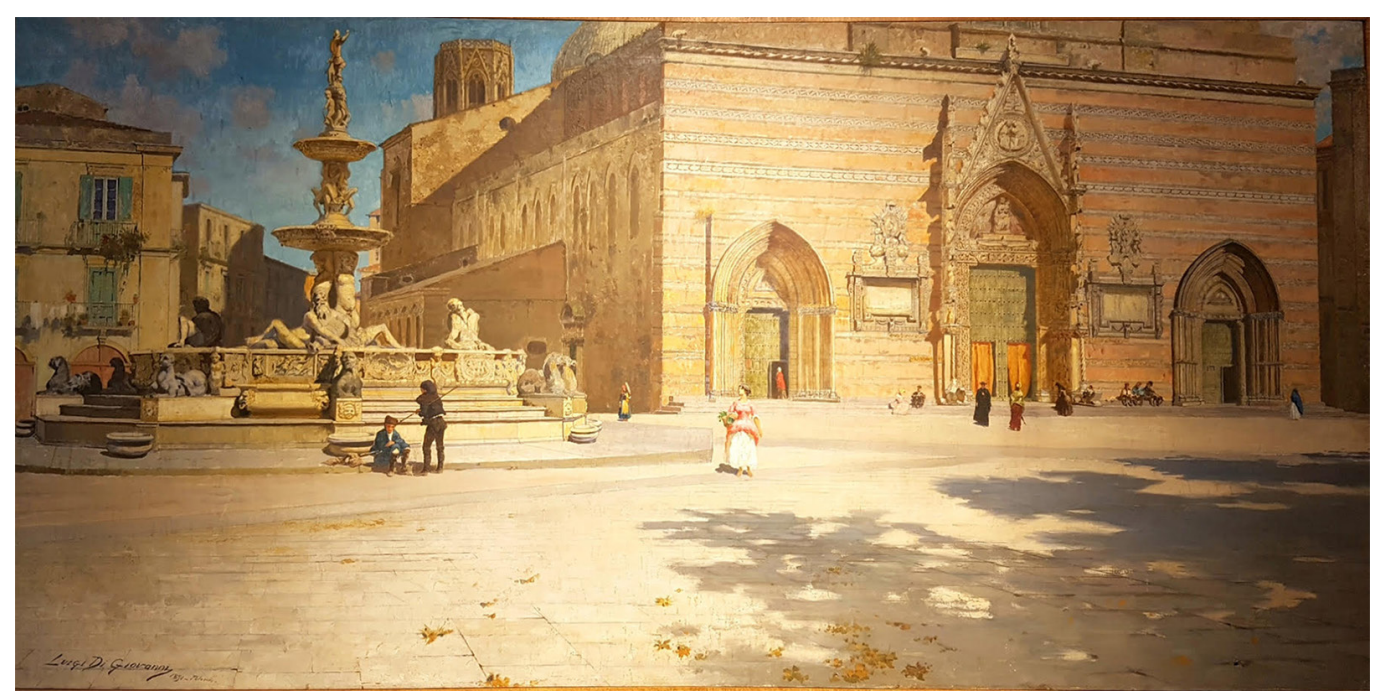

\section{I disegnatori ottocenteschi}

Durante tutto il XIX secolo l'insegnamento del Disegno a Messina trova spazio prevalentemente all'interno della Scuola di Disegno e Pittura del Collegio Carolino e presso la cattedra universitaria

del Collegio di Belle Arti prima e della Facoltà di Scienze a partire dal I870. L'operato dei suoi docenti più rappresentativi si distingue per l'adesione agli stilemi romantici ma ugualmente rispettosi del valore comunicativo e documentario del disegno. Per ciò che riguarda 
la fonte di Orione sono stati analizzati i rilievi di Michele Panebianco (1806-1873) e del palermitano Luigi Di Giovanni ( 856 - 1938). II primo esegue una prospettiva frontale (disegno senza data realizzato a matita su carta, mm $256 \times 306$ e conservato a Messina presso la Biblioteca Regionale G. Longo). Pur non raggiungendo la precisione e l'accuratezza nel dettaglio di Hittorff, tuttavia nel disegno non viene "trascurato" alcun elemento scultoreo e la terza dimensione conferisce maggiore corporeità all'insieme denunciando la formazione prettamente artistica del suo autore (fig. 6). Il secondo esegue invece una serie di studi preparatori sulla fontana raccolti in un taccuino conservato presso il Mu.Me. (Museo Regionale Interdisciplinare di Messina). I bozzetti vengono realizzati probabilmente in vista della preparazione di una veduta della piazza del Duomo di Messina (esposta anch'essa al Mu.Me.) [3] e ciò sembra confermato osservando lo schizzo della parte sommitale della fontana rappresentata con la medesima angolazione riprodotta poi nella tela. Interessante notare, nel bozzetto che raffigura la formella ovale all'interno della quale è rappresentato Icaro che muore cadendo in mare, la citazione di Maurolico che sarà l'autore dei distici collocati sotto le statue raffiguranti le divinità fluviali. Con la stessa metodologia messa in atto da Hittorff, nel suo taccuino Di Giovanni esegue una sorta di scomposizione dei vari pezzi analizzandone, nel suo caso, dal punto di vista morfologico le singole caratteristiche e indicandone la relativa collocazione (destra, sinistra o centro) procedura che, con buona probabilità, lo avrebbe supportato nella rappresentazione complessiva del monumento (figg. 7, 8). (Ad.A.).

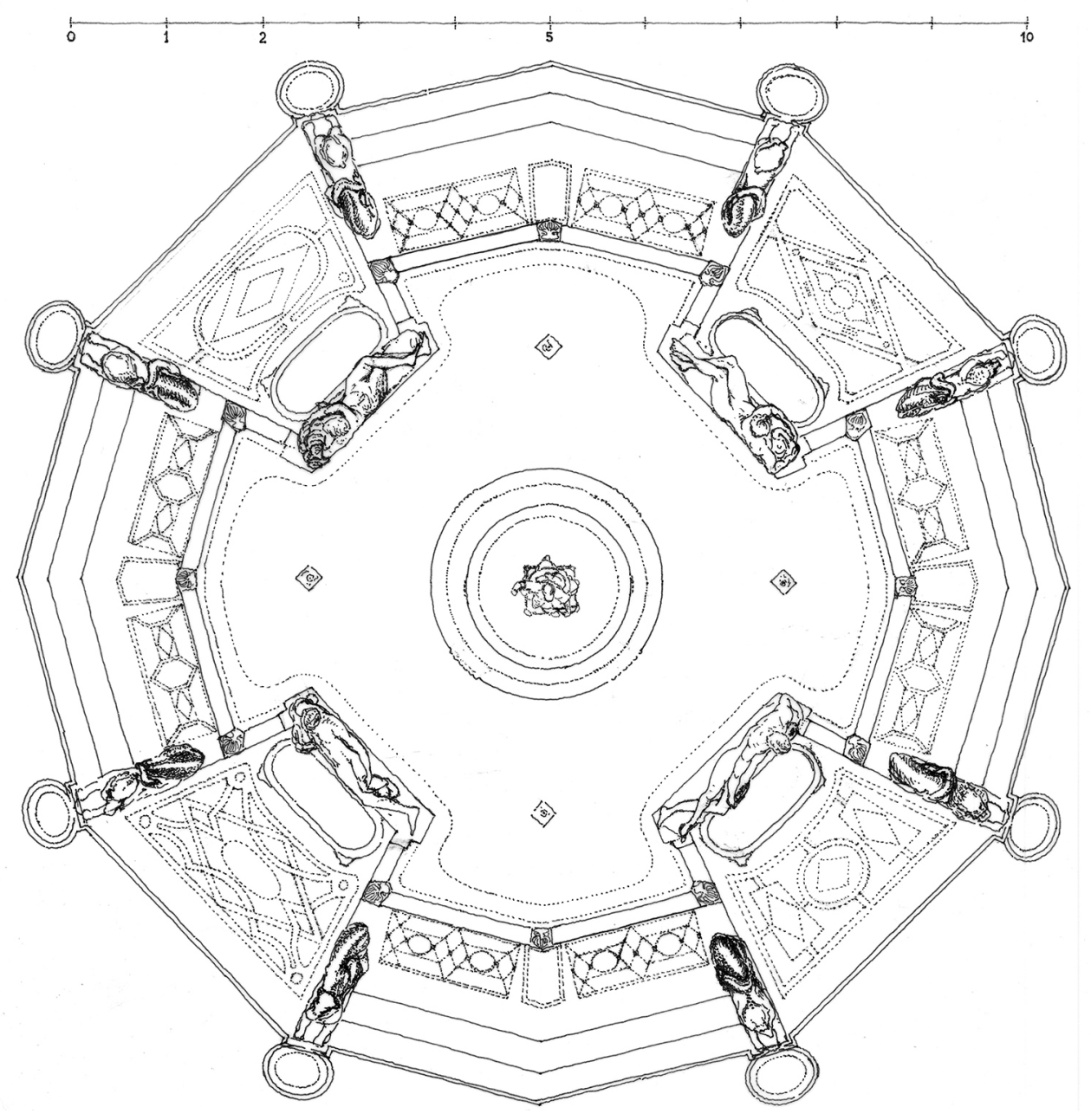




\section{II rilievo integrato e infografico del 2014}

A quasi duecento anni dalla pubblicazione dei rilievi di Hittorff (I 835 Hittorff - 20 I 4 equipe del Dipartimento di Ingegneria) [4] si è proceduto a un rilievo integrato del gruppo scultoreo: numerosi schizzi dal vero, sia di dettaglio che generali, eseguiti da Mario Manganaro (fig. 9), e una battuta di scansioni laser ( 13 punti stazione per 27 scansioni) hanno integrato le conoscenze sul manufatto con la precisa volontà di approfondire scientificamente e criticamente, e di meglio comprendere i rilievi già noti, anche nell'ottica di un progetto di restauro (fig. I0). Sin da subito è stato evidente che l'oggetto da rilevare era un complesso che all'esterno dimostrava una mirabile espressività scultorea, ma che in pari tempo celava una struttura geometrica-architettonica particolarmente adatta ad essere investigata con l'approccio di rilievo con tecnica laser scanner; la costruzione del modello digitale tridimensionale avrebbe potuto svelare, infatti, già in prima battuta, alcune novità.

Giova sottolineare che, nella letteratura dell'opera, il sistema strutturale-costruttivo non è stato attenzionato come meritava, limite superato dal rilievo 3D che ha consentito una conoscenza del monumento più completa e funzionalmente orientata rispetto ai dati già acquisiti e disponibili. Purtroppo la parte basamentale e sotterranea è stata tralasciata in attesa di un successivo rilievo della volta a botte anulare, sulla quale poggiano le sculture dei mostri dal corpo di pesce.

II rilievo ha consentito di valorizzare le geometrie di progetto dell'assemblaggio del monumento, correlandole col disegno strutturale in grado di proiettare la composizione, dall'importante valore estetico, dei tanti tasselli anche di materiali e pesi così diversi (fig. I I). La geometria della base della fontana è una figura, che partendo da un dodecagono irregolare convesso, si modifica in poligono, anch'esso irregolare ma concavo e convesso, di venti lati, di cui otto lati più corti che non raggiungono il metro (su questi lati insistono dei bassorilievi incorniciati da ovali con l'asse maggiore verticale, in cui si trovano immagini di ninfe, putti e altri esseri di raffinata esecuzione). Dalle restituzioni grafiche, effettuate attraverso il ridisegno sulle ortofoto generate dalla nuvola complessiva, confrontate con le incisioni di Hittorff eseguite sul riassemblaggio dei disegni di rilievo, emerge una mancanza di corrispondenze tra testa, forma del corpo, parte posteriore caudata dei mostri di pietra lavica; le code dei

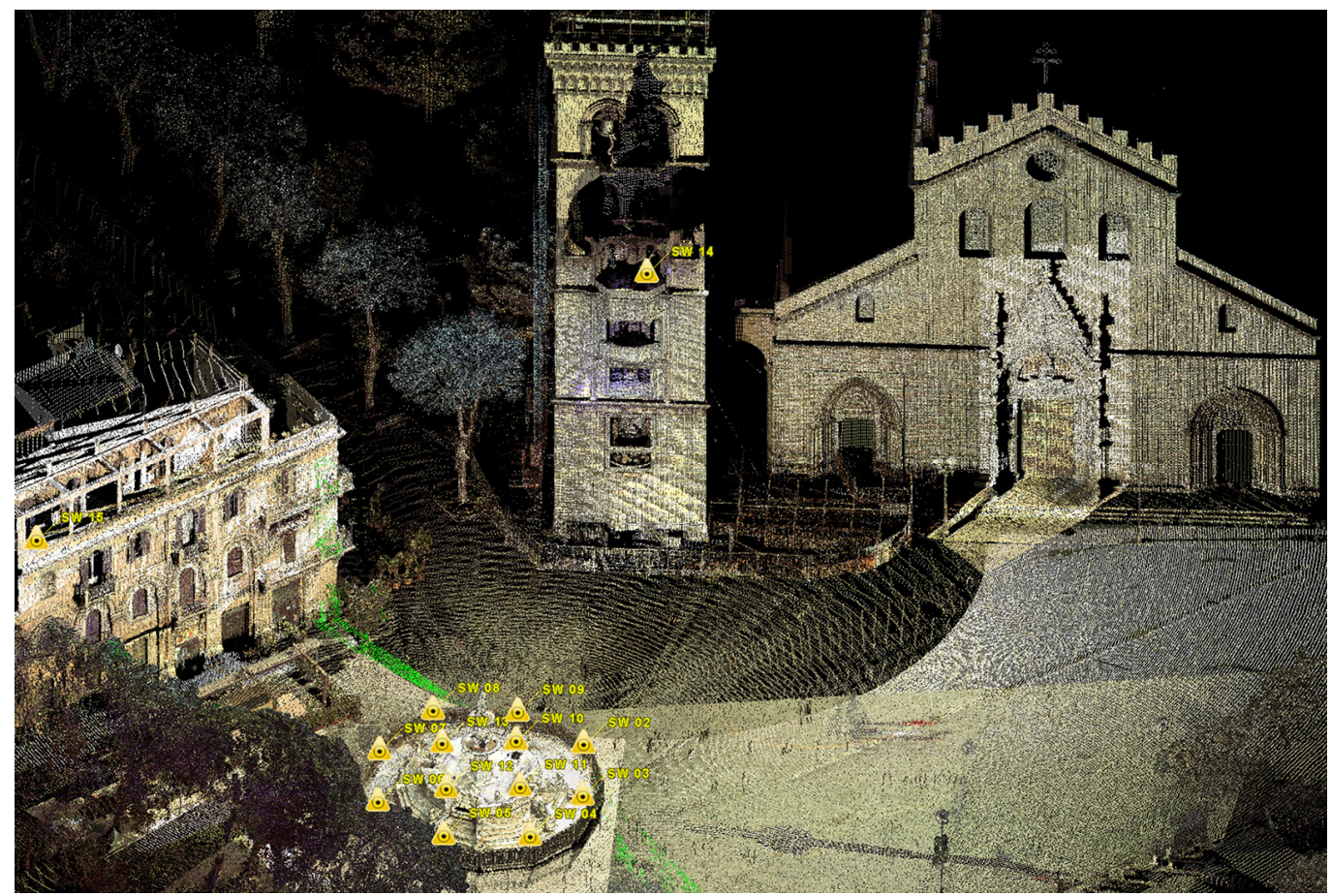


mostri si concludono considerando le statue dei fiumi sempre verso il lato esterno, sia da una parte che dall'altra, eccetto per il Tevere, dove i mostri che stanno ai suoi lati (con le teste di aquila e di leone) buttano la coda verso l'interno (fig. I2). (A. A.).

\section{Conclusioni}

Il lavoro di ricerca qui esposto, che non vuole essere naturalmente esaustivo sull'argomento, in cui vengono proposte, attraverso un excursus temporale di più cinque secoli, le rappresentazioni più conosciute della fontana di Orione a Messina, assegna ancora una volta al disegno un ruolo insostituibile nella trasmissione della conoscenza della storia dell'architettura che, in questo caso, nasce dal confronto tra elaborati prodotti in epoche e contesti culturali diversi. Come sostiene Roberto de Rubertis dall'osservazione dei documenti grafici "si traggono con consapevolezza ... notizie sui modi, sui linguaggi e sulle finalità dell'architettura già concepita, e si desumono quindi, indirettamente, anche i giudizi che su determinate opere furono dati in passato da chi le riprodusse con disegni" [de Rubertis 1996, p. 7].

A partire dalla seconda metà del XVI secolo, epoca in cui l'architetto disegna in prospettiva non tanto per avere una verifica progettuale quanto per una sorta di autocompiacimento estetico determinato dalla verosimiglianza del disegno con l'opera che sarebbe stata realizzata, passando dai disegnatori/rilevatori settecenteschi e ottocenteschi fino alle rappresentazioni contemporanee, gli elaborati analizzati ripercorrono un significativo spaccato della storia della rappresentazione restituendoci importanti occasioni di riflessione sull'evoluzione dei metodi e delle tecniche utilizzati.

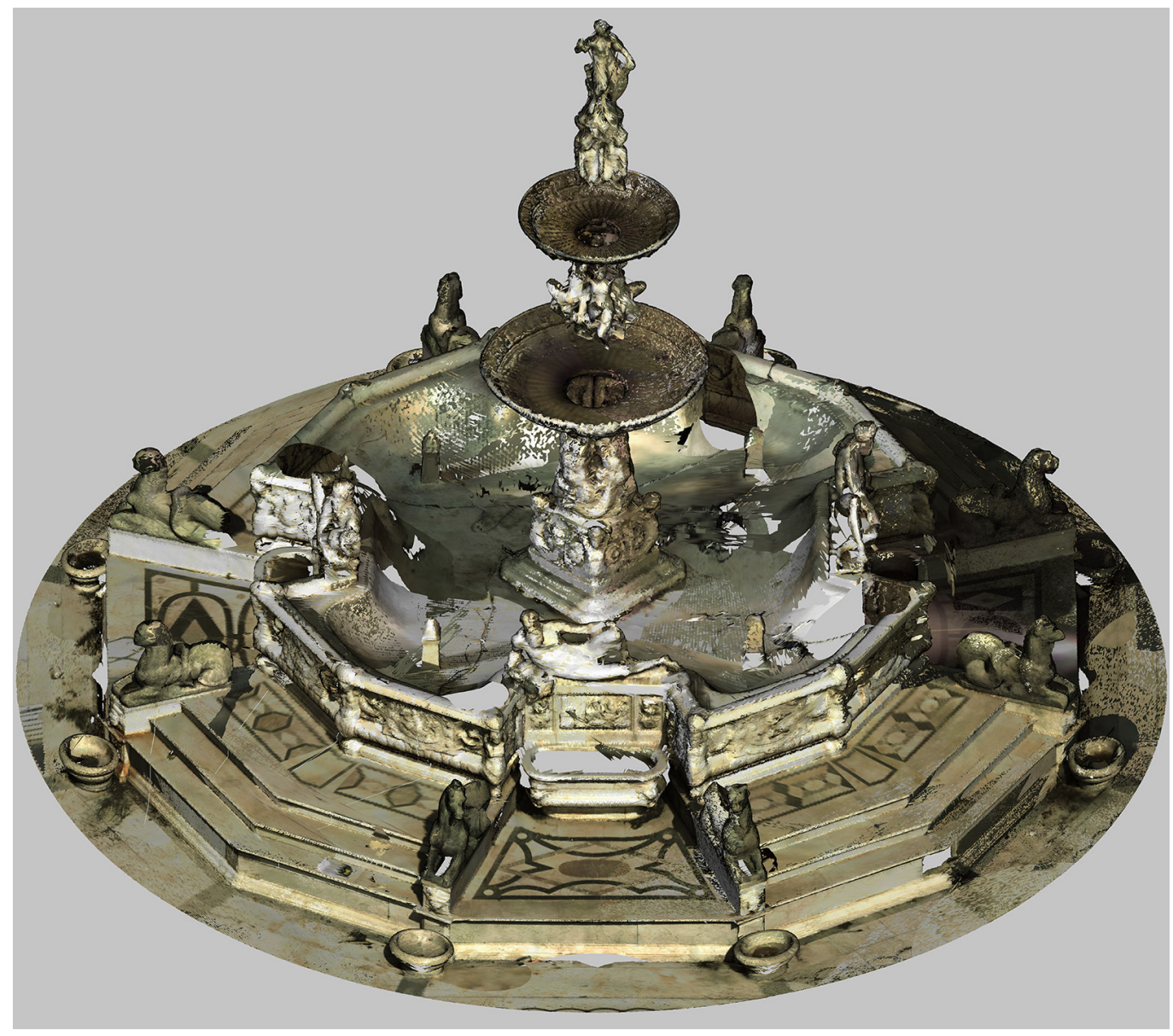


Fig. 12. Sovrapposizione tra ortofoto dalla nuvola di punti (tratto nero) il prospetto del fium Tevere dai rilievi di Hittorff (tratto rosso). Differenze tra due tecnologie di rilievo.
Tra gli obiettivi più significativi conseguiti nell'ambito di questa ricerca c'è sicuramente quello determinato dalla sovrapposizione, come si è visto, dei rilievi eseguiti nel 2014 con i disegni di Hittorff grazie al quale è stato possibile individuare il grado di approssimazione che contraddistingue questi ultimi pur rimanendo altissimo il loro valore in quanto testimonianza di un approccio analitico sicuramente all'avanguardia per l'epoca in cui vengono prodotti, distinguendosi dai precedenti realizzati per lo più a scopo divulgativo o celebrativo o per finalità didattiche.

Ulteriori confronti risulterebbero di difficile giustificazione considerato l'approccio dei rilevatori moderni che, come si è visto nel nostro caso, rispetto al passato operano diversamente sul soggetto architettonico e sulla sua restituzione grafica non solo attraverso l'utilizzo di strumenti evoluti, ma anche concettualmente in funzione delle diverse finalità del rilievo (A.A.).

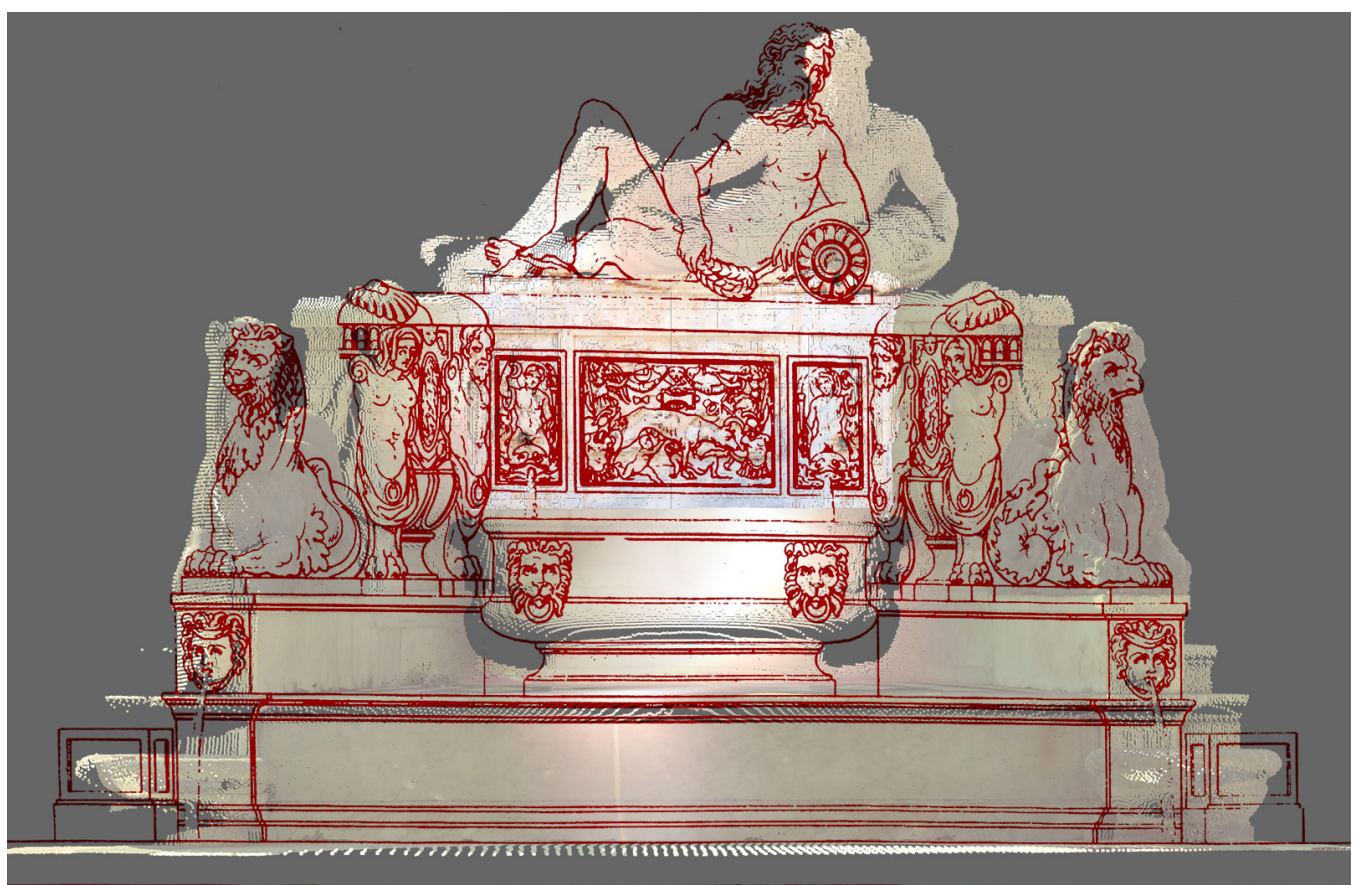

Note

[I] Pier Paolo Ottonello (200 I). Disegno, Ordine, Significato. In THĖMES 7/200।.

[2] Giorgio Vasari dedica un capitolo delle sue Vite a fra Giovann'Agnolo Montorsoli raccontandone in maniera dettagliata il soggiorno a Messina e le opere che vi realizza e tra queste la fontana di Orione che viene descritta con dovizia di particolari. Vasari ( 1878). Le vite de' più eccellenti pittori, scultori ed architettori. Edizione con nuove annotazioni e commenti di Gaetano Milanesi, pp. 629-660.

[3] La tela in questione trova spazio originariamente all'interno della galleria di belle arti allestita a Palermo in occasione dell'Esposizione Nazionale Italiana del $189 \mid$

[4] Del gruppo di lavoro era responsabile scientifico il prof. Mario Manganaro e ne faceva parte, oltre allo scrivente, il geometra Giuseppe Martello.

\section{Riferimenti bibliografici}

Ackerman S. J. (2003). Architettura e disegno. La rappresentazione da Vitruvio a Gehry. Milano: Mondadori Electa.

Altadonna A. (2017). II rilievo come conoscenza complessa e integrata: il caso di studio della fontana di Orione in Messina. In M. Kiene, M. D'Angelo, M. Lo Curzio (a cura di). 1823 Hittorff a Messina. La scoperta di una città nuova, pp. 183-191. Messina: EDAS La Volta, Collana di Studi e Progetti di Architettura. 
Aricò N. (20|3). Architettura del Tardo Rinascimento in Sicilia. Giovannangelo Montorsoli a Messina (1547-57). Firenze: Leo S. Olschki Editore.

Bustamante A., Marías F. (199I). Album di Fra Giovanni Vincenzo Casale. In J. M. Barbeito et al. (a cura di). Disegni Italiani di Architettura e Ornamentazione della Biblioteca Nazionale di Madrid. Secoli XVI e XVII (trad. it. a cura di Corrá Miatto A.), pp. 35-7I . Milano: Biblioteca Nazionale Braidense.

de Rubertis R. (1996). Prefazione. In F. Quici. Il disegno cifrato. Ermeneusi storica del disegno di architettura, pp. 7-9. Roma: Officina Edizioni.

de Saint-Non R. (I78I-I 786). Voyage pittoresque ou description du ou description des royaumes de Naples et de Sicile, vol. IV. Paris: Dufour -Chaillou Potrelle.

Di Giacomo C. (1998). II disegno a Messina fra i due secoli: retaggi accademici ed impulsi innovativi. In G. Barbera (a cura di). Gli Anni dimenticati. Pittori a Messina tra otto e novecento, pp. I03-11।. Messina: Sicania.

Foderà L. (a cura di). (1982). Architecture moderne de la Sicile/Jacques Ignaz Hittorff et Ludwig Zanth. Palermo: Flaccovio.

Houël J. ( I735- I I 3). Voyage pittoresque des isles de Sicile, de Malte et de Lipari, vol. II. De L'imprimerie de Monsieur.

Kiene M. (20I3). Die alben von Jakob Ignaz Hittorff. Das album "Sicile moderne", zeichnungen von einer pilgerfahrt ins wahre paradies den künste. Koln: USB Köln.

Kiene M., D'Angelo M., Lo Curzio M. (2017). I 823 Hittorff a Messina. La scoperta di una città nuova. Messina: EDAS La Volta, Collana di Studi e Progetti di Architettura.

Lanzarini O. ( | 998- 1999). I| codice cinquecentesco di Giovanni Vincenzo Casale e i suoi autori. In Annali di Architettura, n. I 0 - I I. pp. $183-202$.

Lévi-Strauss C. (1 962). La Pensée sauvage. Paris: Plon. Ediz. italiana: Caruso P. ( 1 964). II pensiero selvaggio. Milano: II Saggiatore.

Manganaro M. (20 I7). Rilievo della fontana di Orione. Rapporto preliminare. In M. Kiene, M. D'Angelo, M. Lo Curzio (a cura di). 1823 Hittorff a Messina. La scoperta di una città nuova, pp. 165- |8I. Messina: EDAS La Volta, Collana di Studi e Progetti di Architettura.

Ottonello P. P. (200 I). Disegno, Ordine, Significato. In THÈMES n. 7: <http://www.philosophiedudroit.org/ottonello,\%20disegno. htm> (consultato il 9 gennaio 202I)

Vasari G. ( I 878). Le vite de' più eccellenti pittori, scultori ed architettori. Edizione con nuove annotazioni e commenti di G. Milanesi Tomo III. pp. 629-660. Firenze: G.C. Sansoni.

Autori

Alessio Altadonna, Università di Messina, aaltadonna@unime.it

Adriana Arena, Università di Messina, adarena@unime.it

Per citare questo capitolo: Altadonna Alessio, Arena Adriana (2021). I linguaggi della rappresentazione: i disegni della fontana di Orione a Messina tra il XVI e il XXI secolo/The Languages of the Representation: the Drawings of the Orion Fountain in Messina between the $16^{\text {th }}$ and the $21^{\text {th }}$ Century. In Arena A., Arena M., Mediati D., Raffa P. (a cura di). Connettere. Un disegno per annodare e tessere. Linguaggi Distanze Tecnologie. Atti del $42^{\circ}$ Convegno Internazionale dei Docenti delle Discipline della Rappresentazione/Connecting Drawing for weaving relationship. Langugges Distances Technologies. Proceedings of the $42^{\text {th }}$ International Conference of Representation Disciplines Teachers. Milano: FrancoAngeli, pp. 37-60. 


\title{
The Languages of the Representation: the Drawings of the Orion Fountain in Messina between the $16^{\text {th }}$ and the $21^{\text {th }}$ Century
}

\author{
Alessio Altadonna \\ Adriana Arena
}

\section{Abstract}

Starting from the well-established consideration that drawing is an irreplaceable communication tool, it is that, in relation to the different professional experiences of the authors and to their historical context or to the different recipients or users of their works, the graphic result assumes such characteristics as to be adequately perceived, the paper offers an excursus on the iconographic apparatuses relating to the fountain of Orion, built in Messina in the 16th century. From the analysis of the drawings it is possible to trace interesting paths of knowledge and in-depth analysis on the history of the ways of representing architecture from the period in which the object was conceived up to the present day, also noting the different degrees of approximation that distinguish the drawings with respect to the real object.

Keywords

graphic language, representation, survey, Orion fountain, Messina.

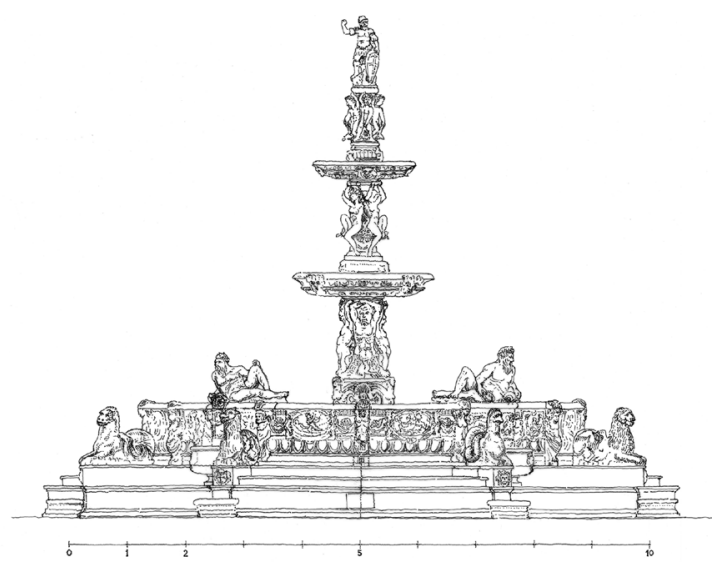




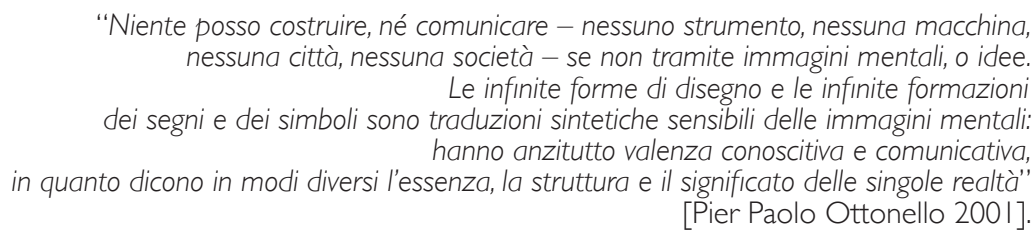

\section{Introduction}

Starting from the well-established consideration that drawing is an irreplaceable communication tool, it is that, in relation to the different professional experiences of the authors and their historical context or to the different recipients or users of their works, the graphic result assumes characteristics such as to be adequately perceived, it is possible to trace interesting paths of knowledge and study on the history of the ways of representing architecture. Paths that take on specific connotations if the object of study is always the same analyzed through the language of its various representations made over the centuries. This kind of investigation presupposes an in-depth knowledge of the ways in which, over the centuries, the interpretation of architectural design has developed, a subject which, obviously, here, can only be mentioned for some points and which will be the starting point for further developments. research in the future. The object in question is the monumental fountain of Orion ( 16 th century) which stands in the square of the cathedral of Messina. (Ad.A.).

\section{Brief historical and descriptive notes}

In 1547 Giovanni Angiolo Montorsoli, a friar of Florentine origins and a pupil of Michelangelo Buonarroti, arrived in Messina with the task of designing a monumental fountain "con un ornamento grandissimo di statue" [Arico 20 I3, p. I] in the square in front of the cathedral to replace a small spring considered the conclusion of an important hydraulic engineering operation conducted to harness the waters of the Camaro river to serve the city. The creation of the fountain becomes the occasion per "avviare un progetto rinascimentale e riscrivere una palingenesi del luogo più rappresentativo della città" [Aricò 20 I3, p. I3].

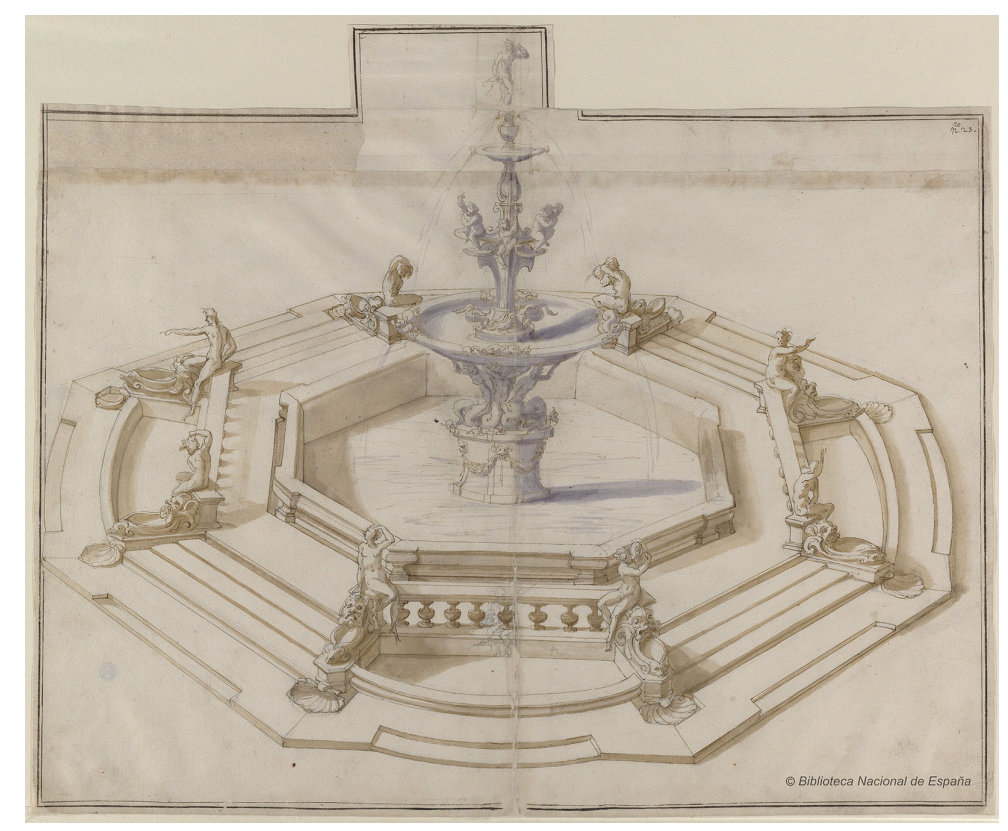


The works were completed in 1550 and the monument was inaugurated three years later. Considered one of the most beautiful fountains in Italy, it will be of interest to local artists and foreign travelers who, in different ways, and with different methods of representation, will reproduce it, or describe its forms in literary texts [Vasari I568] [2], producing an interesting iconographic corpus from which to draw hints for thought about drawing and its various forms of representation. According to the studies conducted by Mario Manganaro, from a geometric point of view, the fountain rests on an irregular dodecagonal base: "Il fatto che non sia un poligono regolare non è casuale, perché la vera figura geometrica della vasca, essendo un poligono concavo ... è formata da venti lati. Considerando, infatti, altri otto lati, ognuno dei quali non raggiunge il metro, dal punto di vista geometrico bisogna aggiungerli agli altri per avere il totale del perimetro" [Manganaro 2017, p. I7I]. More than a sculptural object, historians speak of an architecture "nascosta" by the sculpture, the decorative apparatus is so impressive that it takes the observer's attention away from its compositional structure: a geometric system based on the number 4 for which the main tub stands on a base consisting of three steps whose geometric pattern is interrupted by four recesses with pools, decorated laterally by masks and flanked by sea monsters, on which as many river divinities loom: the Nile, the Tiber, the Ebro and the Camaro (local water source). The water flows through amphorae owned by these statues to flow into the basins below and then into other smaller ones located at the foot of the steps. The elevation of the large pool is decorated with mythological-themed bas-reliefs. From the center rises a group of monstrous figures that supports the second basin from which, in turn, four female sculptures rise, the nymphs, which support the smaller basin with four putti in the center on whose shoulders the statue of Orion with the faithful weighs Sirius dog. (Ad.A.).

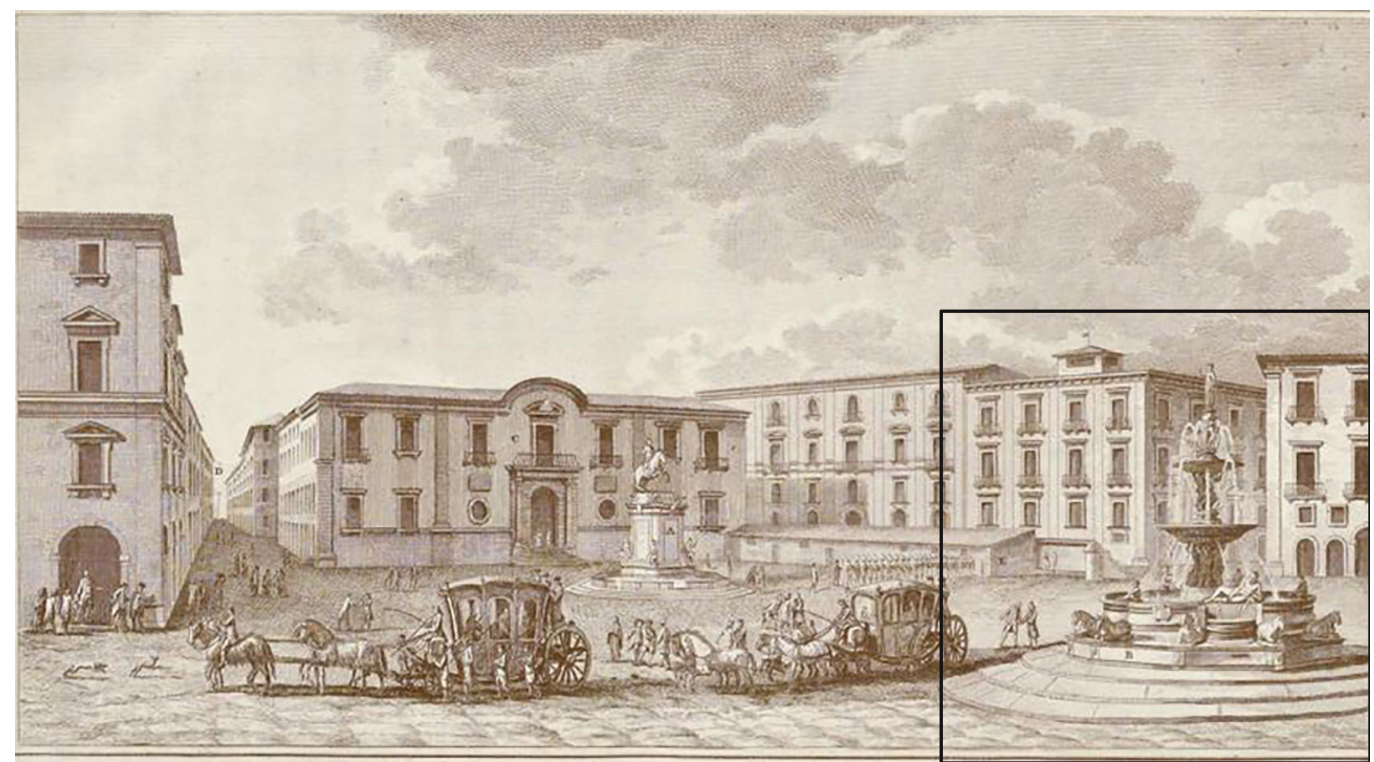

\section{The Casale album}

At the National Library of Madrid, in the collection Dibujos de arquitectura, there is a collection of drawings which takes its name from its author, the friar Giovanni Vincenzo Casale, sculptor and architect and pupil of Montorsoli. Within the album, among others, there are some drawings attributed to the author of the Orion fountain and, precisely of the latter, there is one of the earliest known representations. This is a prospective study, dated I 547, made with black pencil overhauled in ink with sepia and blue watercolors [Bustamante, Marías |99|]. The representation in perspective is part of the drawing practice of Italian Re- 
naissance architects, typically coming from an artistic background, in contrast with the masters of northern Europe who, instead, anticipate the almost systematic use of the method of orthogonal projections in the design of Gothic architecture [Ackerman 2003]. Compared to the current structure, the base has a multilinear trend, like an octagon with the first step alternately assuming a curved or rectilinear shape interrupted, in correspondence with the eight sculptures of the divinities (in the current one there are four), by a cusp. There are four lower tanks on the sides of which the statues are placed at an angle between the end of a balustrade and masks from which the water would have flowed into smaller tanks. After the base structure, the octagonal shape is confirmed in the definition of the main basin in the center of which, on a circular section pedestal, enriched laterally by decorative festoons, a sculptural group of figures supports the second basin. From this, a further pedestal with a variously articulated shape and embellished at the base by four figures of birds and higher up by as many putti, supports the summit basin on which Orione the founder of the city stands. By carefully analyzing the drawing, you can see the splashes of water that fall from above onto the underlying levels, giving it a realistic character (fig. I). Not having available other drawings relating to the monument attributable to its designer, it is not possible to formulate hypotheses relating to the second thoughts that led to the definitive solution. In fact, the drawing of the Casale album remains a precious testimony of a way of representing in a specific historical period: the subsequent variants and studies conducted by historians would suggest an evolution in the thought of its creator aimed at enhancing both geometric complexity than decorative of the monument, aspects just hinted at in the drawing contained in the album. (Ad.A.).

\section{The engravings by Francesco Sicuro and Pierre Gabriel Berthault}

Although on a less detailed scale because they are included in urban views, the comparison between the representations of the monument made by Francesco Sicuro (1746-1826) and published within the Voyage pittoresque des isles de Sicile, de Malte et de Lipari (1735-1813, vol. II) of Jean-Pierre Louis Laurent Houël and from Pierre Gabriel Berthault (I737-1831)

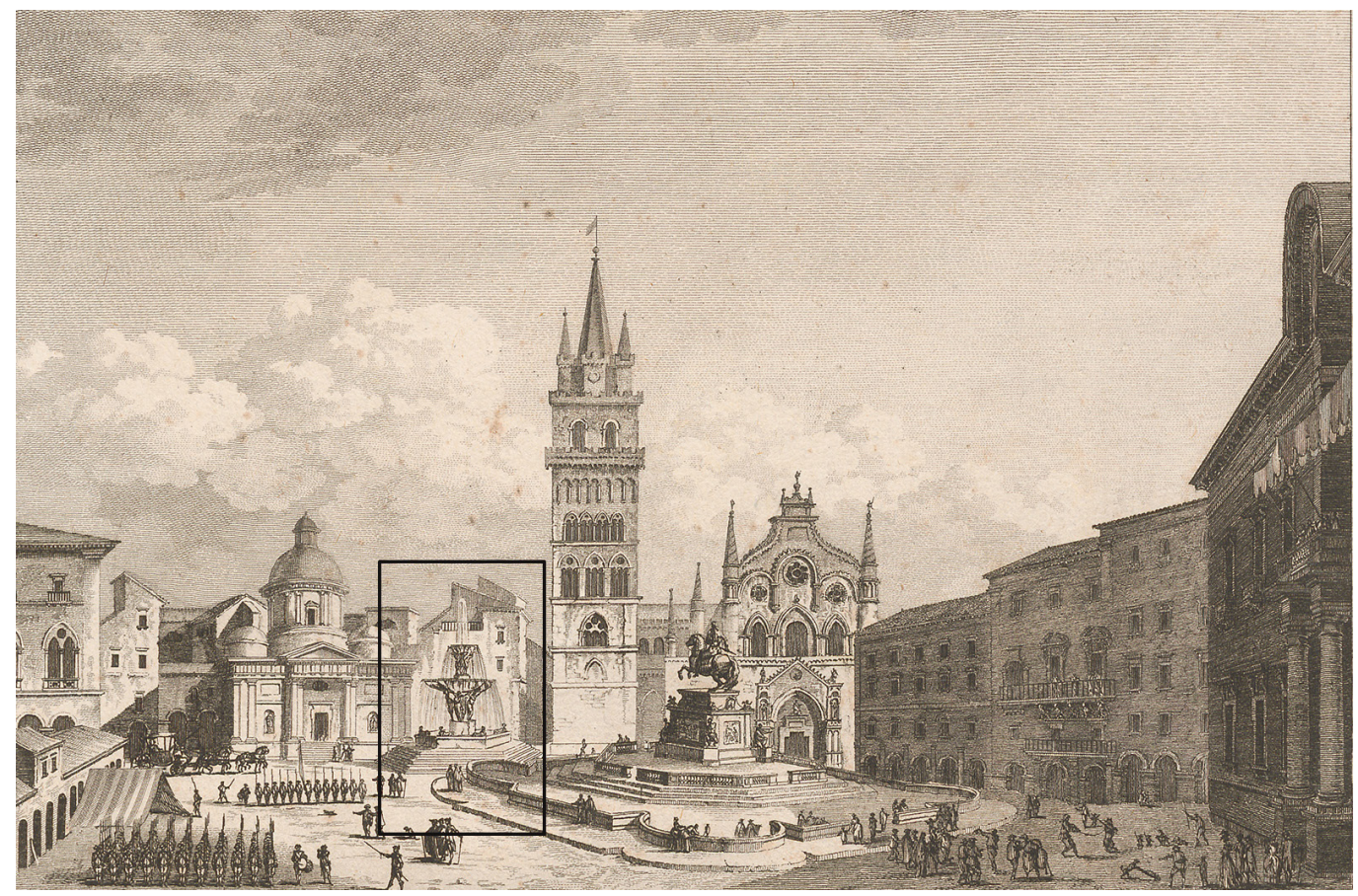


and part of Voyage pittoresque ou description des royaumes de Naples et de Sicile ( I78 I - I 786 vol. IV) of Richard de Saint-Non.

In describing the work Houël speaks of it as of "une très-belle fontaine de marbre ornée de beaucoup de figures d'hommes \& d'animaux" and Sicuro represents it by turning the observer's back towards the cathedral, leaving part of it in the shade. Even in the summary of the description, the main sculptural elements of the work are clearly distinguished and the presence of human figures next to it gives a general idea of the perception of the monumentality of its proportions (fig. 2).

Saint-Non speaks of it as of "une jolie fontaine d'eaux jaillissantes" which together with the equestrian monument of the Spanish king Charles II contribute to defining the ornamental aspect of the square. In Berthault's engraving, the base of the fountain seems to take on a hexagonal shape, giving momentum, with its greater vertical development than the real one, to the base part of the work (fig. 3). The small dimensions, in both cases, determine "una sorta di inversione del processo della conoscenza: per conoscere l'oggetto reale nella sua totalità, noi tendiamo sempre ad assumere come punto di partenza le sue diverse parti ... La riduzione di scala inverte questa situazione: più piccola la totalità dell'oggetto appare meno temibile, per il fatto di essere quantitativamente diminuita, essa ci sembra qualitativamente semplificata" [Lévi-Strauss 1964, pp. 34 et seq.]. (Ad.A.).

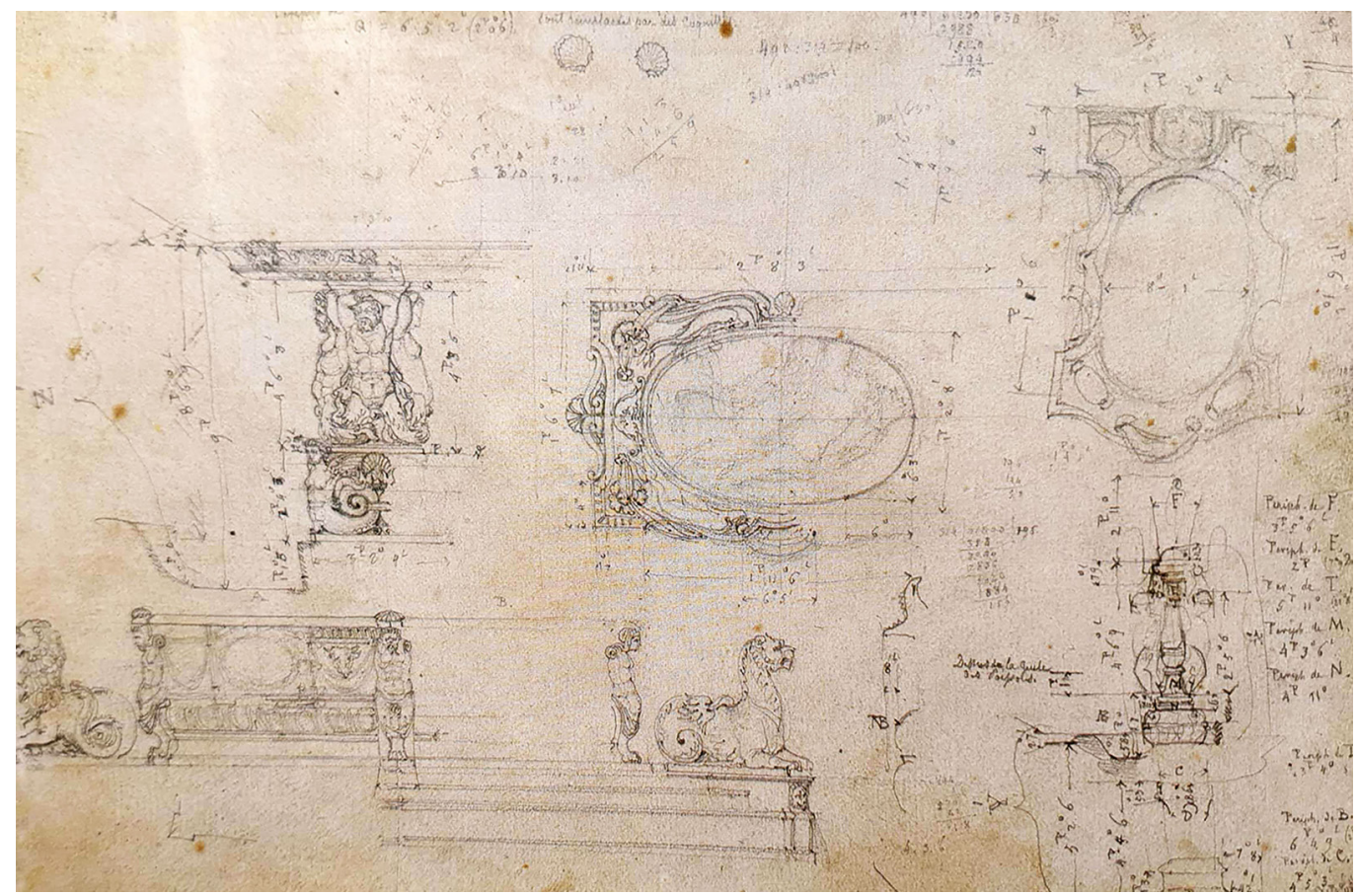

\section{Jacob Ignaz Hittorff surveys}

In 1823, the German architect Jacob Ignaz Hittorff, together with Ludwig Wilhelm von Zanth and Wilhelm Stier, during a stay in Sicily carried out a series of surveys of the Orion fountain still considered to be among the finest in existence today and kept in the Cologne Library. To the planches inserted in the Architecture moderne de la Sicile (1835), the preparatory drawings and the original metric surveys are added from which, thanks to recent publications [Kiene 2013], it was possible to formulate new reflections on the operational methodologies implemented by Hittorff who go beyond "la logica e la pratica tipica della letteratura delle esperienze di viaggio" [Lo Curzio 20 17, p. 49]. 
Fig. 5. Jacob Ignaz Hittorff, Plan et élévation partielle de la grande fontaine sur la place de la Cathédrale a Messine (from: J. I.

Hittorff, L. Zanth autore... Architecture moderne de la Sicile, 1835, tav. n. 26).

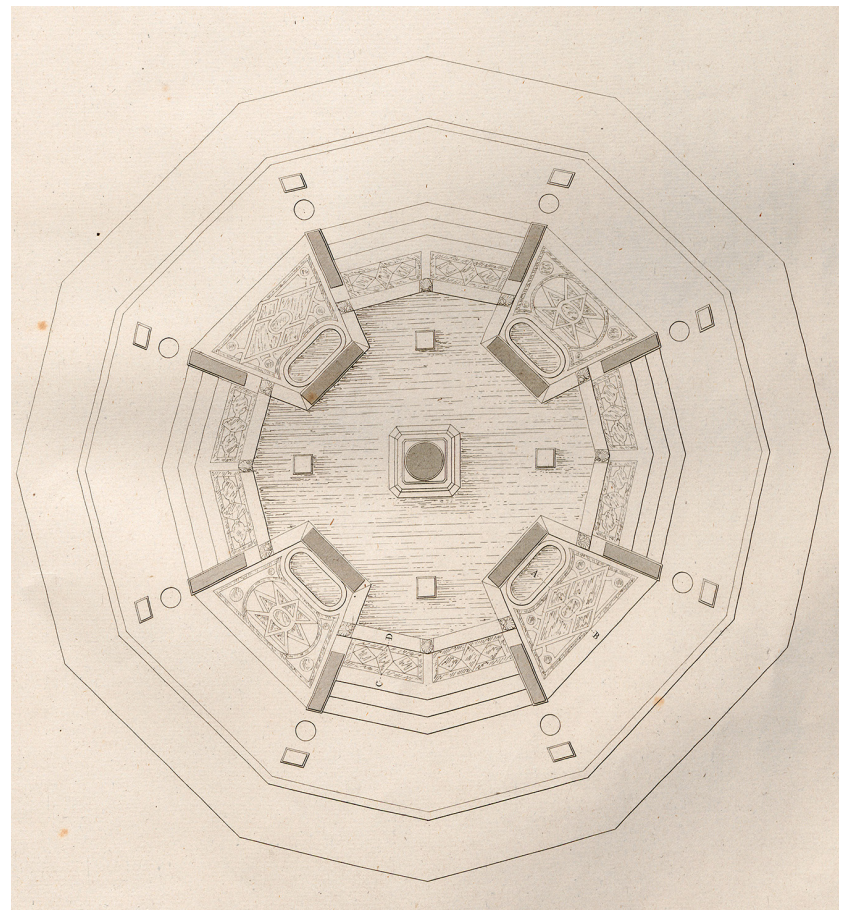

The meticulous approach to the survey and the resulting graphic restitution testify to an attention to the monument that goes far beyond its artistic aspects, enhancing its catalytic role in the urban space in which it is located. Not being able to isolate the contribution of each of the three detectors within the individual drawings, it is however possible, from the comparison between the published drawings and the originals, to formulate considerations on the trait which, in the latter, appears confident and casual in outlining the figures and the decorations, although they are preparatory drawings, on the dimensional information, certainly exhaustive and detailed, all elements that denote the strong neoclassical imprint and the spirit of the Enlightenment that inform the entire survey operation [Manganaro 2017, p. I66] (fig. 4): it is interesting to note the choice, for the horizontal projection of the entire sculptural complex, of several section planes at different heights, perhaps to highlight the

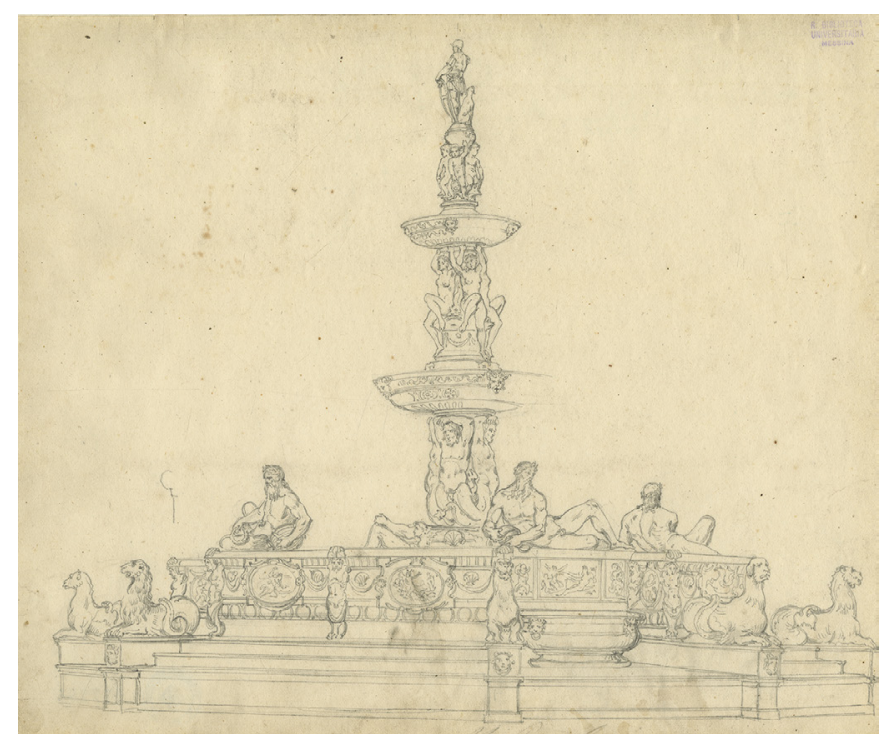


Fig. 7. Luigi Di Giovanni, Preparatory sketches for the fountain of Orion, s.d. (Regional Museum of Messina)

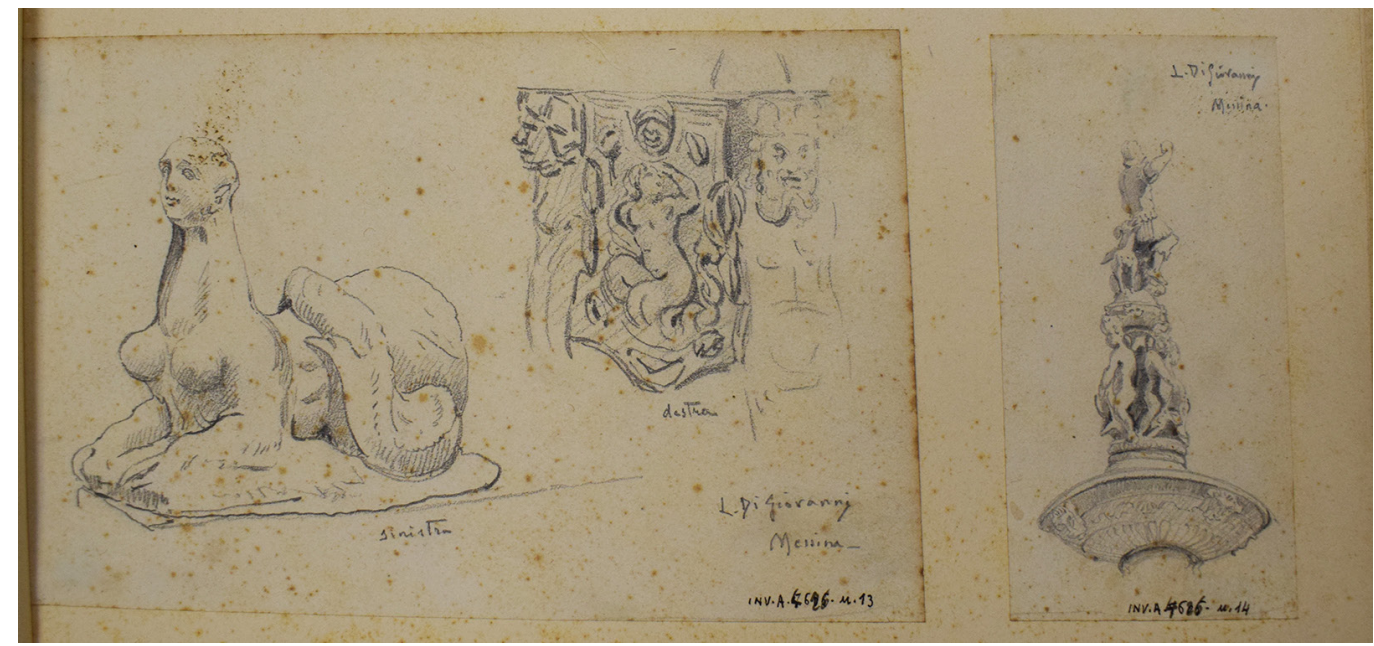

salient features of the work in a single graph (fig. 5). The use of orthogonal projections, introduced and disseminated by Monge with the publication of his work Géométrie descriptive ( I 799), on the other hand, it is the trait that characterizes and makes Hittorff's work unique from that of his predecessors travelers and from other designers with a greater inclination towards the picturesque models that will follow it "con le proiezioni geometriche di Monge, la quotatura e le vedute prospettiche, è possibile ricostruire scientificamente ed interamente gli edifici esaminati attraverso un'astrazione che esclude l'uso soggettivo del chiaroscuro o delle ombre che potrebbero determinare un effetto pittorico o prevaricare il senso nitido ed obbiettivo della costruzione architettonica" [Foderà 1982, p. 89]. (Ad. A.).

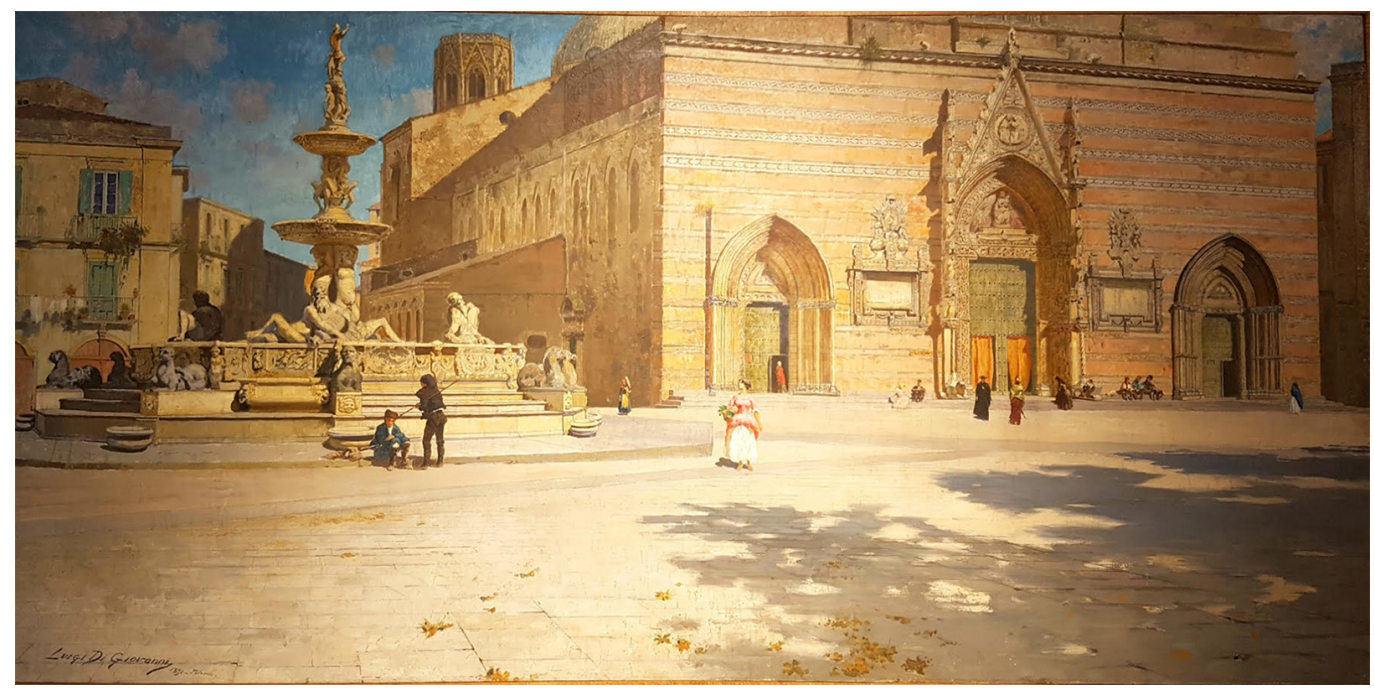

\section{The nineteenth-century drawers}

Throughout the nineteenth century, the teaching of Drawing in Messina found space mainly within the School of Drawing and Painting of the Collegio Carolino and at the College of Fine Arts and of the Faculty of Sciences since 1870. The work of its most representative teachers is distinguished by the adherence to the romantic styles but equally respectful of the communicative and documentary value of the design. As regards the fountain of Orione, the surveys by Michele Panebianco (1806-1873) and Luigi Di Giovanni (I856-1938) from 
Palermo have been analyzed. The first performs a central perspective (undated drawing made in pencil on paper, 256×306 mm and kept in Messina at the G. Longo Regional Library). While it does not reach Hittorff's precision and accuracy in detail, in the drawing is not "trascurato" no sculptural element and the third dimension gives greater corporeality to the whole by denouncing the purely artistic experience of its author (fig. 6). The second instead performs a series of preparatory studies on the fountain collected in a notebook kept at the Mu.Me. (Regional Interdisciplinary Museum of Messina). The sketches are probably made in view of the preparation of a view of the Piazza del Duomo in Messina (also exhibited at the Mu.Me.) [3] and this seems to be confirmed by observing the sketch of the top part of the fountain represented with the same angle reproduced then in the canvas. It is interesting to note, in the sketch depicting the oval panel in which Icarus is depicted falling into the sea, the quote from Maurolico who the author of the couplets will be placed under the statues depicting the river gods. With the same methodology implemented by Hittorff, in his notebook Di Giovanni performs a sort of decomposition of the various pieces, analyzing, in his case, the individual characteristics from the morphological point of view and indicating their relative location (right, left or center). which, in all probability, would have supported him in the overall representation of the monument (figs. 7, 8). (Ad.A.).

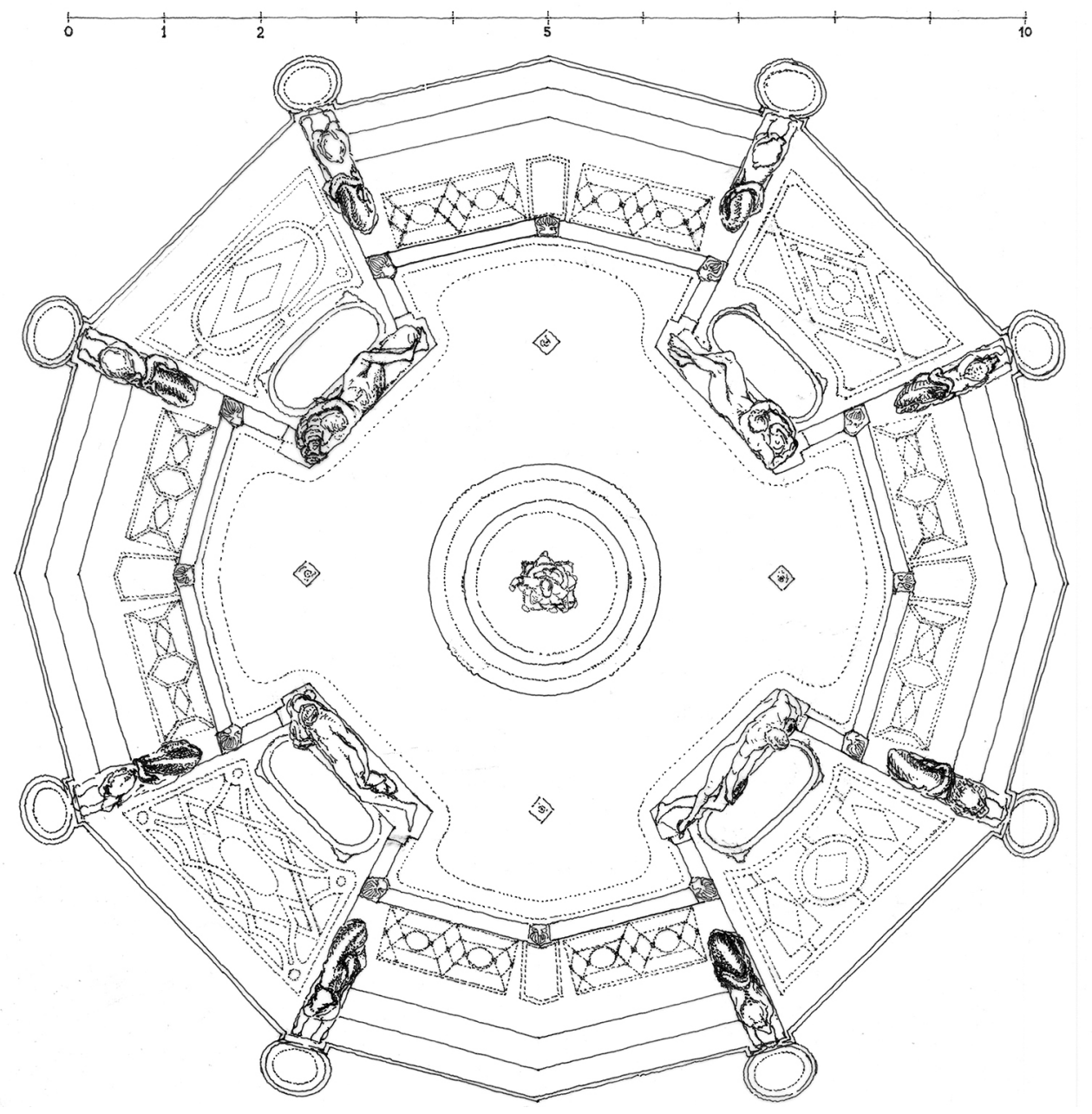




\section{An integrated and infographic survey of 2014}

Almost two hundred years after the publication of Hittorff's reliefs (I 835 Hittorff - 2014 Engineering Department team) [4], an integrated survey of the sculptural complex was carried out, engaging numerous free hand general and detailed sketches performed by Mario Manganaro (fig. 9) with a sequence of laser scans ( 13 station points for 27 scans), in the precise desire to integrate scientifically and critically the knowledge on the artefact. Thus, in order to understand better the achieved documented surreys, in view for a design renovation (fig. I0).

From the very beginning, it was evident that the object to be surveyed was a complex that on the outside showed an admirable sculptural expressiveness, but which at the same time concealed a geometric-architectural structure particularly suitable for being investigated with the survey approach engaging a laser scanner technique. The construction of the three-dimensional digital model could have revealed, in fact, already in the first instance, diverse novelties.

It should be emphasized that, within the documented literature, the structural-construction system wasn't sensibly highlighted as merited. This was exceeded by the 3D survey which allowed a more complete and functionally knowledge of the monument respect to the data already acquired and obtained. Despite of the fact that the basement and underground part has been left out from the survey analyses, pending for a subsequent relief of the annular barrel vault, on which rest the enormous fish body sculptures.

The survey made it possible to enhance the design geometries of the monument configuration, correlating them with the structural design, capable in forming a composition, with significant aesthetic values, of various elements different in materials and weights (fig. I I).

The fountain base geometry is a figure which, starting from an irregular convex dodecagon, changes into a polygon also irregular but concave and convex of twenty sides, and eight are less than a meter. On these laterals are located bas-reliefs, framed by ovals with a major vertical axis, in which there are images of nymphs, cherubs and other beings of refined execution.

From the graphic rendering, carried out by the orthophoto redesign generated through the global point cloud, and compared with Hittorff's engravings by reassembling the relief

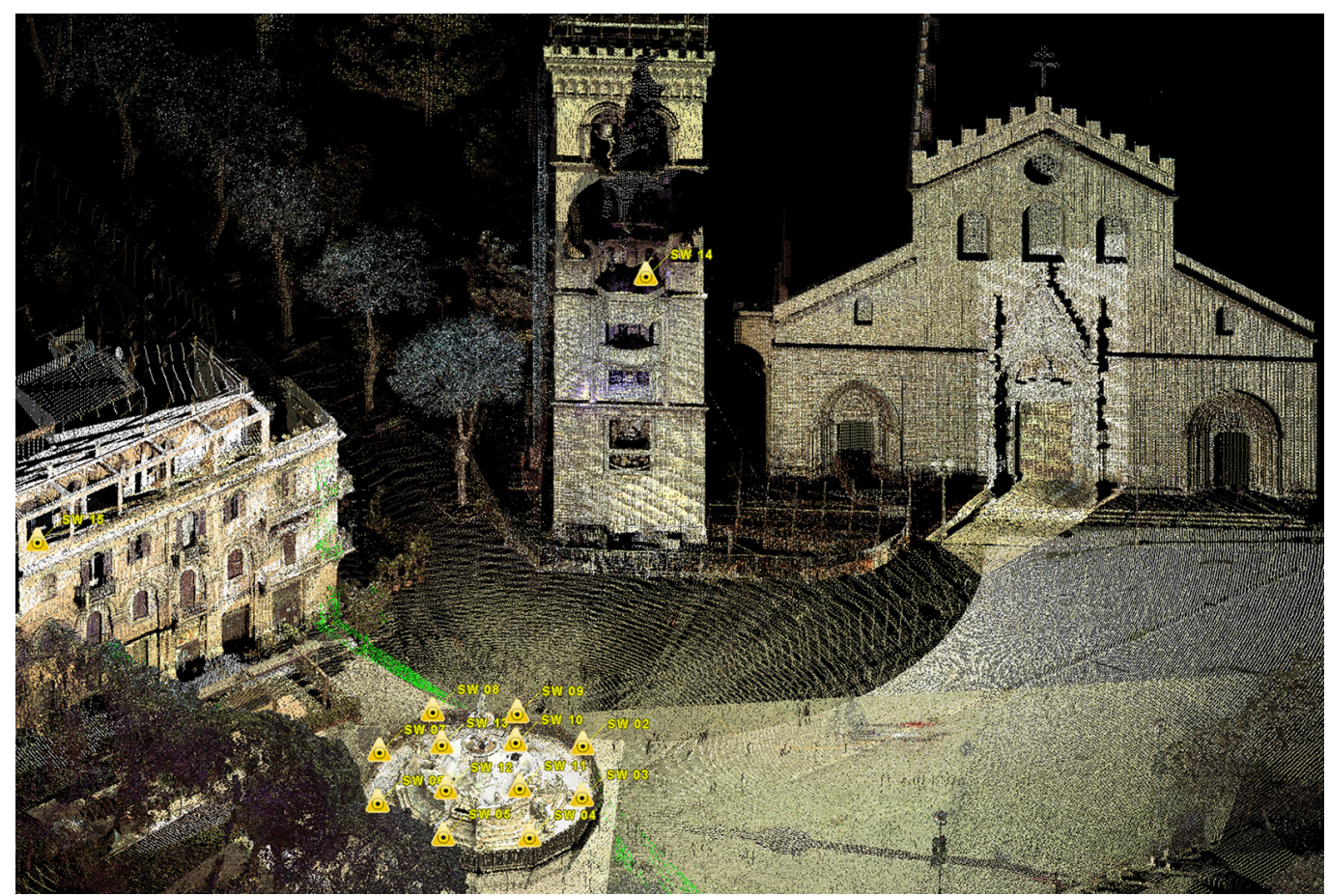


drawings, emerges a lack of correspondence near the head, the body shape and rear tail of the lava stone monsters. The tails of the monsters, respect to the statues of the rivers, point outwards, on one side and the other, except for the Tiber, where the monsters (with the heads of eagles and lions) throw the tail inwards (fig. 12). (A.A.).

\section{Conclusions}

The research work exhibited here, which does not naturally want to be exhaustive on the subject, in which the best known representations of the Orion fountain in Messina are proposed, through a temporal excursus of more than five centuries, once again assigns a role to drawing irreplaceable in the transmission of knowledge of the history of architecture which, in this case, arises from the comparison between drawings produced in different eras and cultural contexts. As Roberto de Rubertis argues from the observation of graphic documents "si traggono con consapevolezza ... notizie sui modi, sui linguaggi e sulle finalità dell'architettura già concepita, e si desumono quindi, indirettamente, anche i giudizi che su determinate opere furono dati in passato da chi le riprodusse con disegni" [de Rubertis 1996, p. 7]. Starting from the second half of the sixteenth century, an era in which the architect draws in perspective not so much to have a design check as for a sort of aesthetic self-satisfaction determined by the likelihood of the drawing with the work that would have been created, passing from the draftsmans/surveyors from the eighteenth and nineteenth centuries up to contemporary representations, the analyzed works retrace a significant cross-section of the history of representation, giving us important opportunities for reflection on the evolution of the methods and techniques used.

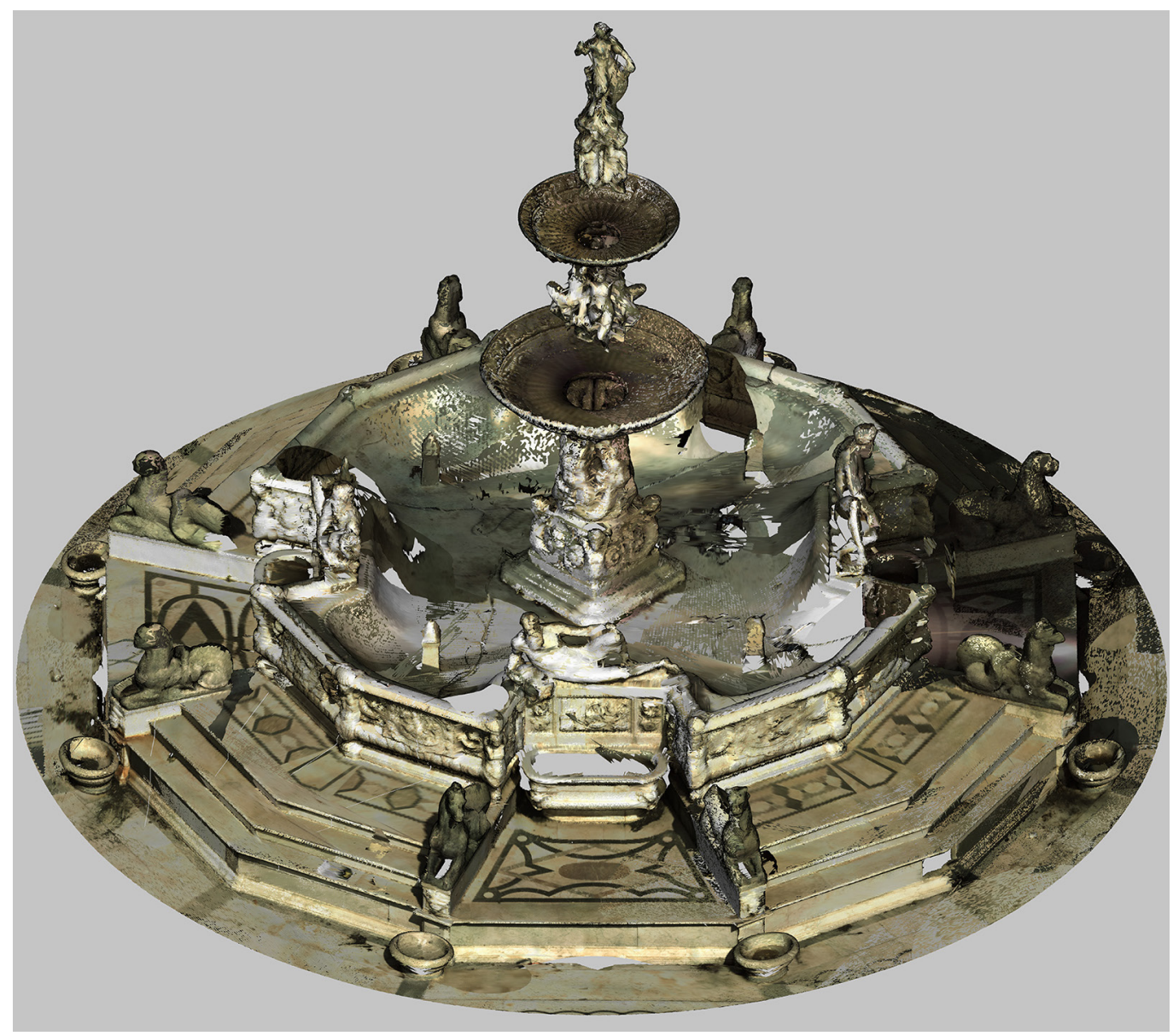


Among the most significant objectives achieved in the context of this research there is certainly the one determined by the overlap, as we have seen, of the surveys carried out in 2014 with Hittorff's drawings thanks to which it was possible to identify the degree of approximation that distinguishes these the latter while remaining very high their value as evidence of an analytical approach certainly avant-garde for the time in which they are produced, distinguishing themselves from the previous ones made mostly for informative or celebratory purposes or for educational purposes.

Further comparisons would be difficult to justify considering the approach of modern surveyors who, as we have seen in our case, operate differently on the architectural subject and its graphic rendering not only through the use of advanced tools, but also conceptually in according to the different purposes of the survey (A.A.).

Fig. 12. The overlapping of the orthophoto point cloud (black line) and

Tiber river from Hittorff's survey (red line).

surferences between the two survey technologies.

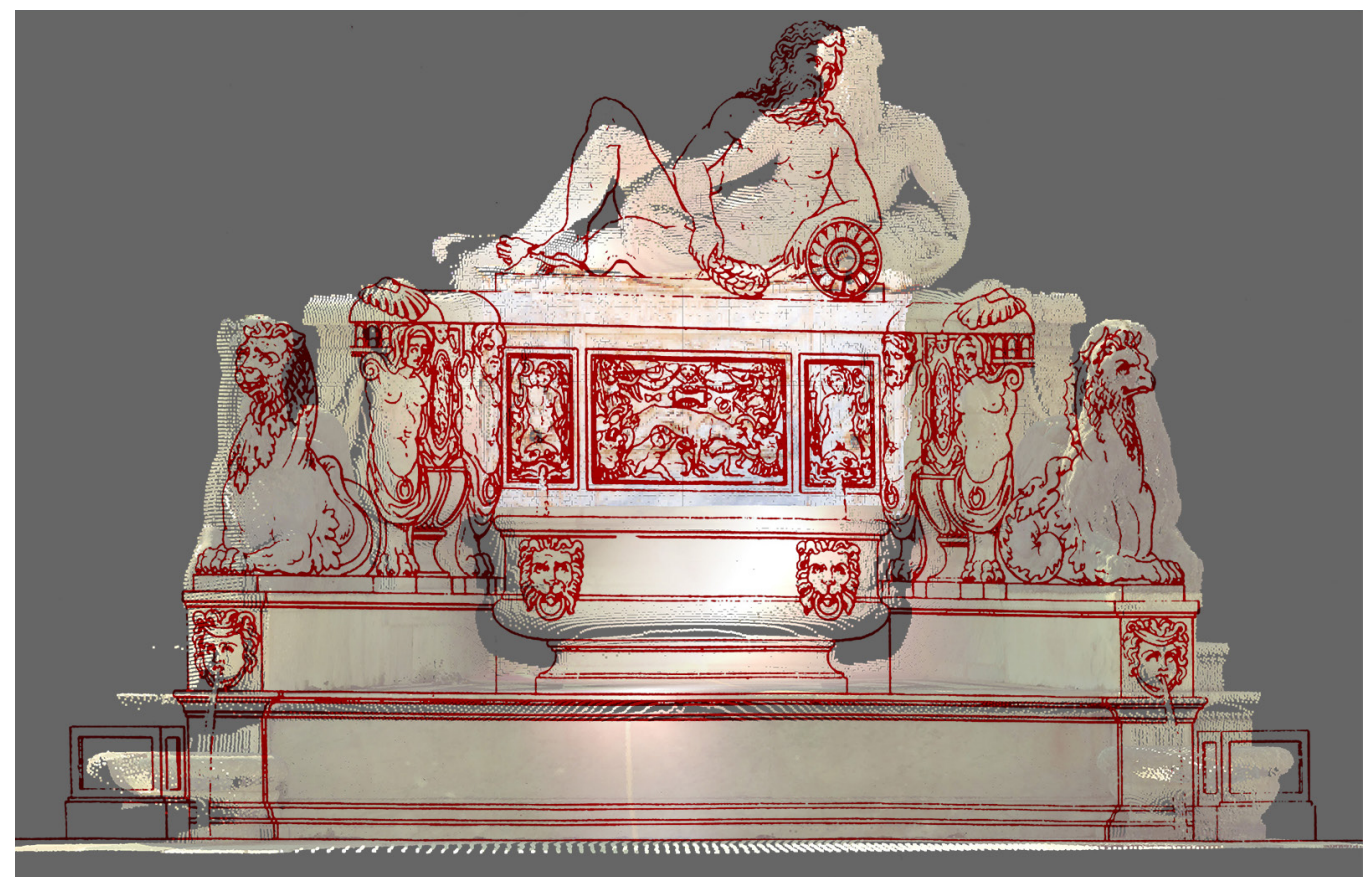

Notes

[I] Pier Paolo Ottonello (200 I). Disegno, Ordine, Significato. In THÈMES 7/200I.

[2] Giorgio Vasari dedicates a chapter of his Lives to Fra Giovann'Agnolo Montorsoli, describing in detail his stay in Messina and the works he creates there, including the fountain of Orion which is described in great detail.Vasari (I878). Le vite de' più eccellenti pittori, scultori ed architettori. Edition with new notes and comments by Gaetano Milanesi, pp. 629-660.

[3] The canvas in question originally found space inside the fine arts gallery set up in Palermo on the occasion of the Italian National Exhibition of |89|.

[4] Professor Mario Manganaro was scientific director of the working group and, in addition to the writer, the surveyor Giuseppe Martella was part of it.

\section{References}

Ackerman S. J. (2003). Architettura e disegno. La rappresentazione da Vitruvio a Gehry. Milano: Mondadori Electa.

Altadonna A. (2017). II rilievo come conoscenza complessa e integrata: il caso di studio della fontana di Orione in Messina. In M. Kiene, M. D'Angelo, M. Lo Curzio (a cura di). 1823 Hittorff a Messina. La scoperta di una città nuova, pp. I83-191. Messina: EDAS La Volta, Collana di Studi e Progetti di Architettura.

Aricò N. (20|3). Architettura del Tardo Rinascimento in Sicilia. Giovannangelo Montorsoli a Messina (1547-57). Firenze: Leo S. Olschki Editore. 
Bustamante A., Marías F. (I99I). Album di Fra Giovanni Vincenzo Casale. In J. M. Barbeito et al. (a cura di). Disegni Italiani di Architettura e Ornamentazione della Biblioteca Nazionale di Madrid. Secoli XVI e XVII (trad. it. a cura di Corrá Miatto A.), pp. 35-7I. Milano: Biblioteca Nazionale Braidense.

de Rubertis R. (1996). Prefazione. In F. Quici. Il disegno cifrato. Ermeneusi storica del disegno di architettura, pp. 7-9. Roma: Officina Edizioni.

de Saint-Non R. (|78|- |786). Voyage pittoresque ou description du ou description des royaumes de Naples et de Sicile, vol. IV. Paris: Dufour -Chaillou Potrelle.

Di Giacomo C. (1998). II disegno a Messina fra i due secoli: retaggi accademici ed impulsi innovativi. In G. Barbera (a cura di). Gli Anni dimenticati. Pittori a Messina tra otto e novecento, pp. I03-III. Messina: Sicania.

Foderà L. (a cura di). (1982). Architecture moderne de la Sicile/Jacques Ignaz Hittorff et Ludwig Zanth. Palermo: Flaccovio.

Houël J. ( 1735- I 13). Voyage pittoresque des isles de Sicile, de Malte et de Lipari, vol. II. De L'imprimerie de Monsieur.

Kiene M. (20I3). Die alben von Jakob Ignaz Hittorff. Das album "Sicile moderne", zeichnungen von einer pilgerfahrt ins wahre paradies den künste. Koln: USB Köln.

Kiene M., D'Angelo M., Lo Curzio M. (2017). 1823 Hittorff a Messina. La scoperta di una città nuova. Messina: EDAS La Volta, Collana di Studi e Progetti di Architettura.

Lanzarini O. ( 1998- 1999). II codice cinquecentesco di Giovanni Vincenzo Casale e i suoi autori. In Annali di Architettura, n. I0- I I, pp. 183-202.

Lévi-Strauss C. (1962). La Pensée sauvage. Paris: Plon. Ediz. italiana: Caruso P. ( I 964). II pensiero selvaggio. Milano: II Saggiatore.

Manganaro M. (2017). Rilievo della fontana di Orione. Rapporto preliminare. In M. Kiene, M. D'Angelo, M. Lo Curzio (a cura di). 1823 Hittorff a Messina. La scoperta di una città nuova, pp. 165- I8I. Messina: EDAS La Volta, Collana di Studi e Progetti di Architettura.

Ottonello P.P. (200 I). Disegno, Ordine, Significato. In THÈMES n. 7: <http://www.philosophiedudroit.org/ottonello,\%20disegno. $\mathrm{htm}>$ (accessed 2021, January 9).

Vasari G. ( 1878). Le vite de' più eccellenti pittori, scultori ed architettori. Edizione con nuove annotazioni e commenti di G. Milanesi Tomo III. pp. 629-660. Firenze: G.C. Sansoni.

\section{Authors}

Alessio Altadonna, Università di Messina, aaltadonna@unime.it

Adriana Arena, Università di Messina, adarena@unime.it

To cite this chapter. Altadonna Alessio, Arena Adriana (2021). I linguaggi della rappresentazione: i disegni della fontana di Orione a Messina tra il $X V \mid$ e il XXI secolo/The Languages of the Representation: the Drawings of the Orion Fountain in Messina between the $16^{\text {th }}$ and the $21^{t}$ Century. In Arena A., Arena M., Mediati D., Raffa P. (a cura di). Connettere. Un disegno per annodare e tessere. Linguaggi Distanze Tecnologie. Atti del $42^{\circ}$ Convegno Internazionale dei Docenti delle Discipline della Rappresentazione/Connecting. Drawing for weaving relationship. Languages Distances Technologies. Proceedings of the $42^{\text {th }}$ International Conference of Representation Disciplines Teachers. Milano: FrancoAngeli, pp. 37-60. 